\title{
Using isotopes to constrain water flux and age estimates in snow-influenced catchments using the STARR (Spatially distributed Tracer-Aided Rainfall-Runoff) model
}

\author{
Pertti Ala-aho $^{1}$, Doerthe Tetzlaff ${ }^{1}$, James P. McNamara ${ }^{2}$, Hjalmar Laudon $^{3}$, and Chris Soulsby ${ }^{1}$ \\ ${ }^{1}$ Northern Rivers Institute, School of Geosciences, University of Aberdeen, AB24 3UF, UK \\ ${ }^{2}$ Department of Geosciences, Boise State University, Boise, ID 83725, USA \\ ${ }^{3}$ Department of Forest, Ecology and Management, Swedish University of Agricultural Sciences, 90183 Umeå, Sweden
}

Correspondence to: Pertti Ala-aho (pertti.ala-aho@abdn.ac.uk)

Received: 24 February 2017 - Discussion started: 9 March 2017

Revised: 28 June 2017 - Accepted: 18 August 2017 - Published: 9 October 2017

\begin{abstract}
Tracer-aided hydrological models are increasingly used to reveal fundamentals of runoff generation processes and water travel times in catchments. Modelling studies integrating stable water isotopes as tracers are mostly based in temperate and warm climates, leaving catchments with strong snow influences underrepresented in the literature. Such catchments are challenging, as the isotopic tracer signals in water entering the catchments as snowmelt are typically distorted from incoming precipitation due to fractionation processes in seasonal snowpack.

We used the Spatially distributed Tracer-Aided RainfallRunoff (STARR) model to simulate fluxes, storage, and mixing of water and tracers, as well as estimating water ages in three long-term experimental catchments with varying degrees of snow influence and contrasting landscape characteristics. In the context of northern catchments the sites have exceptionally long and rich data sets of hydrometric data and - most importantly - stable water isotopes for both rain and snow conditions. To adapt the STARR model for sites with strong snow influence, we used a novel parsimonious calculation scheme that takes into account the isotopic fractionation through snow sublimation and snowmelt.

The modified STARR setup simulated the streamflows, isotope ratios, and snow pack dynamics quite well in all three catchments. From this, our simulations indicated contrasting median water ages and water age distributions between catchments brought about mainly by differences in topography and soil characteristics. However, the variable degree of snow influence in catchments also had a major influence on the stream hydrograph, storage dynamics, and
\end{abstract}

water age distributions, which was captured by the model. Our study suggested that snow sublimation fractionation processes can be important to include in tracer-aided modelling for catchments with seasonal snowpack, while the influence of fractionation during snowmelt could not be unequivocally shown. Our work showed the utility of isotopes to provide a proof of concept for our modelling framework in snowinfluenced catchments.

\section{Introduction}

Tracer-aided hydrological models provide invaluable insights into how water and solutes are partitioned, stored, and transported within catchments (Seibert and McDonnell, 2002; Kirchner, 2006). They can also be used to explore metrics of catchment hydrological function such as water age and travel times, leading to new avenues for use in studying ecohydrological water partitioning and anthropogenic influences (Birkel and Soulsby, 2015). Snow-influenced catchments, particularly in the Northern Hemisphere, have a long history in hydrological modelling with the ultimate goal of reproducing the stream hydrograph where spring snowmelt plays a dominant role (Hinzman and Kane, 1991; Seibert, 1999; Pomeroy et al., 2007). An essential part of this is correctly representing snow accumulation and melt, and importantly its spatial distribution, and as a result numerous tools of variable complexity have emerged to simulate catchmentscale snow processes (Tarboton and Luce, 1996; Lehning et al., 2002; Liston and Elder, 2006). However, using tracer- 
aided models in these regions has been less common (Tetzlaff et al., 2015b) - mainly due to difficulties of routine, longterm field work, and sample collection in such cold and often remote regions. Nevertheless, environmental tracers have been used at some sites to increase conceptual process understanding in the field and for hydrograph separation studies (Sklash and Farvolden, 1979; Laudon et al., 2002; Carey and Quinton, 2004; Schmieder et al., 2016).

Stable water isotopes oxygen-18 and deuterium are commonly used environmental tracers because of their conservative properties and automatic entry to natural systems with precipitation (Birkel and Soulsby, 2015). They are also increasingly easy and inexpensive to analyse in large numbers (Berman et al., 2009). In snow-influenced environments, the cryogenic processes complicate the isotope input signal through several processes. Firstly during snow accumulation snowfalls with different isotopic composition make up the snowpack with distinct isotopic layers typically persisting until the wholesale snowmelt (Rodhe, 1981), though a degree of internal isotopic redistribution is typically present in the snowpack (Taylor et al., 2001; Evans et al., 2016). Internal mixing processes do not considerably influence the bulk isotopic composition of the snowpack, but fractionation due to snow sublimation has the potential to isotopically enrich the snowpack in relation to snowfall (Moser and Stichler, 1974; Earman et al., 2006). Furthermore, canopy snow interception can provide an additional transient storage subjected to sublimation, and thereby fractionation processes, further amplifying the snow isotopic enrichment (Claassen and Downey, 1995; Koeniger et al., 2008). Finally, several field, laboratory, and modelling studies (Shanley et al., 1995; Taylor et al., 2001; Feng et al., 2002) demonstrate how the onset of snowmelt tends to be depleted in heavy isotopes in comparison to average snowpack, and the snowpack isotopically enriches over the course of snowmelt. This "melt-out" process, though a complex and variable phenomenon in field conditions, has been shown by, for example, Taylor et al. (2002) to be rather a rule than exception for snowmelt of seasonal snowpacks in various climates. As a combined results of the processes above, water entering the catchment as liquid is not only delayed in timing because of being stored as snow but is typically also altered in its isotopic composition (Laudon et al., 2002; Schmieder et al., 2016). In most environments such processes have a high degree of spatial variability and are thus challenging to model at the catchment scale.

Historically, tracer-aided model applications have typically been lumped/semi-lumped conceptual models (Neal et al., 1988; Barnes and Bonell, 1996; Hrachowitz et al., 2013; Smith et al., 2016), though some modelling studies incorporate spatial variability in the model parameterization (Stadnyk et al., 2013; Birkel et al., 2015). Spatially and temporally limited tracer data are typically a considerable constraint in tracer-aided modelling (Delavau et al., 2017), in particular if interest lies in understanding spatially distributed flow processes over longer than event timescales. To address this challenge, the Spatially distributed Trace-Aided RainfallRunoff (STARR) model was developed to fully distribute the simulation for hydrological storages, fluxes, isotope ratios and water age in the landscape (Huijgevoort et al., 2016a, b). This follows on from previous conceptual models that have used spatially explicit frameworks for tracking isotopes in the rainfall-runoff transformation (Sayama and McDonnell, 2009). The STARR model was originally developed for a long-term experimental catchment in the Scottish Highlands, the Bruntland Burn, with the aim to keep the model simple to be applicable as a generic tool across northern regions with strong snowmelt influence (Tetzlaff et al., 2015a).

In this study, we apply the STARR model in three wellestablished research catchments with long and frequent data sets of stable water isotopes (Tetzlaff et al., 2017). All experimental catchments experience seasonal snow influence, but are contrasting in their topography, dominant soil types, and canopy cover. The main advancement of the STARR model reported here is replacing the original degree-day snow module with an energy-driven process-based snow module that can track isotopes (Ala-aho et al., 2017b). The novel snow module encompasses original algorithms to account for (1) sublimation fractionation of snow isotopes of canopy intercepted snow and ground snowpack and (2) time-variant depletion of the snowmelt. Both processes are well documented in laboratory, field, and modelling studies (Cooper et al., 1993; Claassen and Downey, 1995; Taylor et al., 2001; Laudon et al., 2002, see e.g. Carey and Quinton, 2004; Koeniger et al., 2008; Schmieder et al., 2016), but have not before been incorporated to tracer-aided modelling in a spatially explicit manner.

The overarching goal for this study is to better understand spatial distribution and non-stationary responses of water ages in snow-influenced northern catchments. We achieve this by using the STARR model to simulate spatially distributed flows, isotopes, and snow water equivalent (SWE) in three long-term experimental catchments. The contrasting catchment characteristics make a strong test for the model adaptability in different cold climate conditions. As a novel aspect, we test new empirical parsimonious routines for stable water isotope processes in seasonal snowpacks in our catchment-scale simulations. A wider importance of our work is in advancing tools for process understanding and management of snow-influenced environments that are underrepresented in research but are on the verge of drastic changes due to global climate change and economic development (Tetzlaff et al., 2015b).

\section{Methods}

\subsection{Study sites}

All three study sites are established, long-term experimental catchments with a wealth of hydrological, ecological, and 
biogeochemical research activities associated with them. We provide a brief description of the catchments; more details are found in the cited publications.

\subsubsection{Krycklan C7}

The most northerly $\left(64^{\circ} 14^{\prime} \mathrm{N}, 10^{\circ} 46^{\prime} \mathrm{E}\right)$ and smallest $\left(0.5 \mathrm{~km}^{2}\right)$ experimental catchment is Krycklan C7 (Fig. 1) in the Swedish boreal forest, approximately $50 \mathrm{~km}$ inland from Umeå and the Baltic Sea (Laudon et al., 2013). Of the three catchments, it has the gentlest relief with altitudes ranging from 235 to $306 \mathrm{~m}$ a.s.l. Annual average precipitation is $622 \mathrm{~mm}$, approximately 35 to $50 \%$ of which falls as snow (Laudon and Löfvenius, 2016). Annual average air temperature is $2.4^{\circ} \mathrm{C}$, with sub-zero monthly mean temperatures typically during November-March. Highest flows in the catchment are typically a result of spring snowmelt during 3-4 weeks in April/May (Fig. 2). Half of the runoff occurs during the snow-free period with higher flows towards autumn. Snow-covered winters from December to March are the annual low-flow season. Most of the land cover is conifer boreal forest $(82 \%)$ with a mix of Scots pine $(P i-$ nus sylvestris) and Norwegian spruce (Picea abies). A small part of the catchment consist of a canopy-free minerogenic mire $(18 \%)$ which is dominated by Sphagnum moss. Except for the organic soils in the mire and riparian areas adjacent to the stream, the catchment is dominated by podzolic soils. The podzolic soils are formed on compact basal till underlain by metasediments. Hydraulic conductivity of the soil decreases with depth with high transmissivity feedback initiated in the top soil with high water tables (Nyberg et al., 2001). In the forested areas with podzolic soils, subsurface flow paths dominate, whereas overland flow takes place in the mire during periods of intense water inputs from rain or snowmelt (Peralta-Tapia et al., 2015a).

\subsubsection{Bruntland Burn}

The Bruntland Burn $\left(57^{\circ} 8^{\prime} \mathrm{N}, 3^{\circ} 20^{\prime} \mathrm{E}\right)$ is located in the Scottish Highlands and of the three catchments is the largest in size $\left(3.2 \mathrm{~km}^{2}\right)$. The catchment has a wide flat glaciated valley bottom surrounded by steeper hillslopes (Fig. 1), with altitudinal relief ranging from 250 to $530 \mathrm{~m}$ a.s.l. Average annual precipitation is $1000 \mathrm{~mm}$, with annually reoccurring, but not dominant (typically $<5 \%$ of annual precipitation), snow influence. Average air temperature is $7.0^{\circ} \mathrm{C}$ without any months with below-negative mean temperatures. Seasonality in streamflow is much less pronounced than for the other two sites because of milder winters and lower snow influence, with peak flows typically taking place between November and February (Fig. 2). Soils in the wide valley bottom riparian areas are Histosols (22\%) with Sphagnum spp. and Molina caerulea vegetation. Organic soils in the valley bottom are underlain by glacial drift up to $30 \mathrm{~m}$ deep creating a considerable groundwater storage and steady ground-

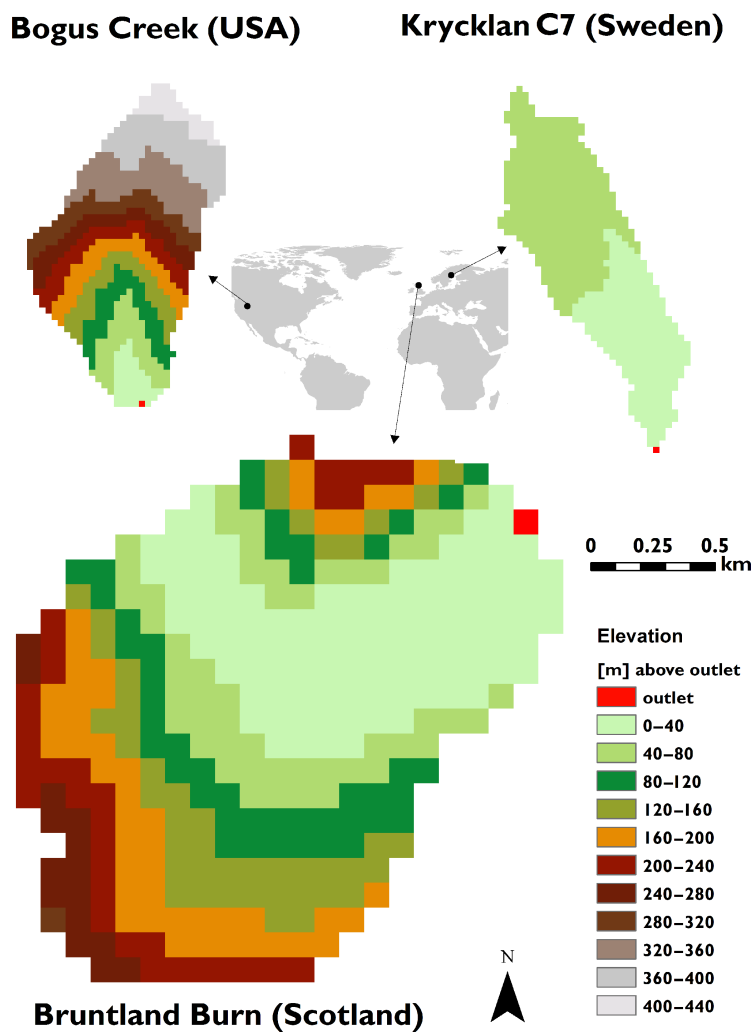

Figure 1. Study sites in same scale for size and same colour scheme for altitude, and location of the sites. Pixel size in the figure equals the cell size of the model ( $25 \mathrm{~m}$ for Bogus and Krycklan, $100 \mathrm{~m}$ for Bruntland).

water flux to riparian areas (Ala-aho et al., 2017a). Steeper slopes have podzolic soils underlain by more freely draining minerogenic soils with heather (Calluna vulgaris) being the dominant vegetation, with patches of Scots pine $(P$. sylvestris) forests. In Bruntland runoff is primarily generated within the persistently saturated riparian areas, with occasional contributions from hillslopes when they became hydrologically connected during large storm events (Tetzlaff et al., 2014).

\subsubsection{Bogus Creek}

The Bogus Creek $\left(43^{\circ} 42^{\prime} \mathrm{N}, 116^{\circ} 10^{\prime} \mathrm{E}\right)$ is the most southerly site located in Idaho, northwest US (Fig. 1). The catchment is similar in size to Krycklan $\left(0.6 \mathrm{~km}^{2}\right)$, but a V-shaped fluvial valley slopes steeply from 1684 to $2135 \mathrm{~m}$ a.s.l., resulting in the highest altitude catchment of the three. The site receives about $670 \mathrm{~mm}$ of precipitation annually, with more than $50 \%$ of it during winter as snowfall, summers being typically hot and dry. Average annual air temperature of $8.8^{\circ} \mathrm{C}$ is the highest among sites, but with below-zero mean monthly temperatures from November to March in the highest parts of the catchment, and in December to February at the catchment outlet. The stream hydrograph reflects the climate with 


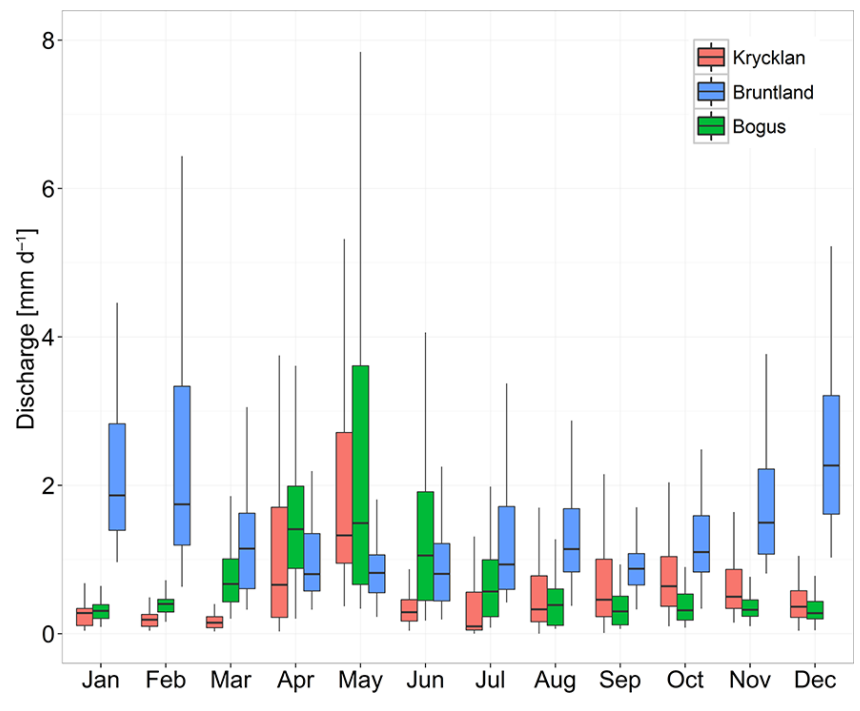

Figure 2. Box plots showing the seasonality of streamflow for each catchment by grouping daily streamflow (5 years of data for Bruntland, 8 for Bogus, and 10 for Krycklan) to monthly bins. Coloured box shows the 25th and 75th quantiles, small horizontal line the median, and vertical line the extent of 5th and 95th percentiles. High flows for Krycklan and Bogus are brought about by snowmelt occurring typically in April-May. For Bruntland, flows are more evenly distributed through the year with highest flow during December-February with occasional snowmelt influence. Colour coding (red for Krycklan, blue for Bruntland, green for Bogus) is maintained throughout the paper.

a snowmelt influence from March to June typically peaking in May, with low flows during the rest of the year (Fig. 2). The soils are thin $(<1 \mathrm{~m})$ highly permeable sands underlain by fractured granodiorite comprising a hydrologically active bedrock groundwater storage. Bitter and choke cherry (Prunus spp.) and buck brush (Ceanothus spp.) shrubs cover most of the catchment, with a small fraction of larger trees (Douglas fir (Pseudotsuga menziesii) and ponderosa pines (Pinus ponderosa)) in the valley bottom near the stream. Runoff generation at the site is subsurface driven and runoff increases only after the water table rises sufficiently (McNamara et al., 2005).

\subsection{Model input and test data}

The experimental catchments studied here have - in a northern context - exceptionally long and high-quality data records for stable water isotopes, streamflow, and meteorological variables. Isotope data from streamflow has been sampled daily for Bruntland Burn, weekly for Krycklan, and more sporadically for Bogus (Fig. 3). Typical variability in stream isotopes over the year (0.05-0.95 quantiles) spans from -7.7 to $-9.3 \%$ in $\delta^{18} \mathrm{O}$ for Bruntland, -12.0 to $-14.0 \%$ in Krycklan, and -15.6 to $-17.4 \%$ in Bogus, showing seasonality with depleted values in winter months

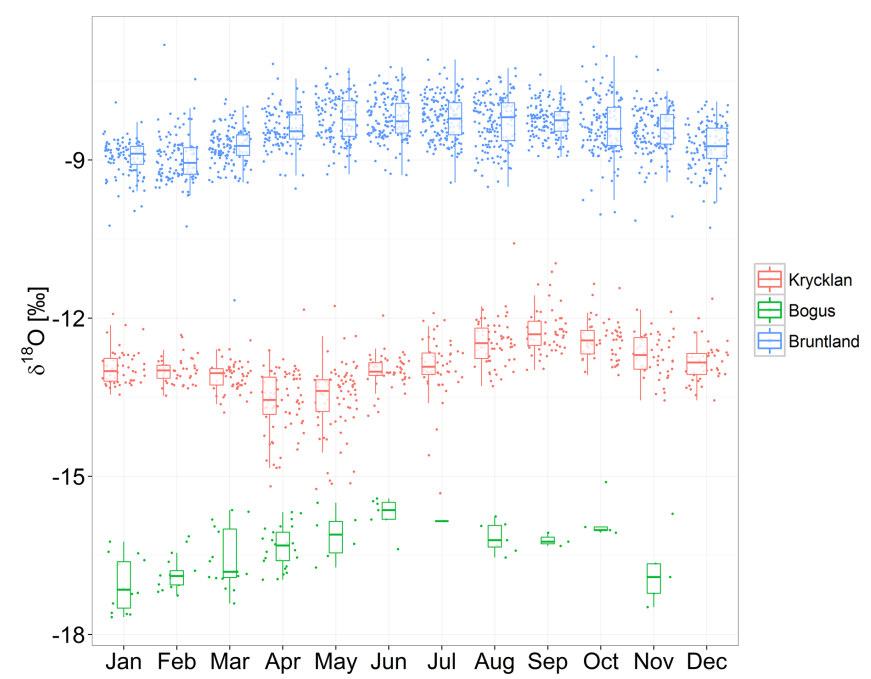

Figure 3. Isotope samples of streamflow for each site grouped into monthly bins where the jitter plots show all data points and box plots summarize the span of the data. For Bogus we show data presented by Kormos (2005) which were not used in model calibration due to problems with the flow data.

and enriched in the summer for all sites. At the Krycklan site we see a distinct snowmelt depletion during April/May. Precipitation samples were available for most precipitation events for Bruntland and Krycklan. For Bruntland only liquid precipitation was sampled because of rarely occurring snowfall events. For Krycklan with more persistent snow cover, precipitation was sampled daily following every snowfall, melted in a cool room $\left(+8^{\circ} \mathrm{C}\right)$, and subsequently measured for volume using a fine-graded measurement cylinder. The occasional missing values are preferentially filled by a value using a representative sample from a nearby catchment, or if not available, backfilled with data from the next available date. For Bogus, we expanded the sparse input data set by applying the following methodology. We used samples from all meteorological stations in the wider Dry Creek Experimental watershed (DCEW, $n=142$ ) to build a linear regression model to estimate continuous time series for precipitation from daily air temperature similarly as in Tappa et al. (2016). In addition, we applied an environmental lapse rate of $-0.22 \%$ ofor $\delta^{18} \mathrm{O}$ per $100 \mathrm{~m}$ rise in elevation established for the DCEW (Tappa et al., 2016). Precipitation isotopes were used as model input data and isotopes in streamflow were used in model calibration at all sites.

Meteorological data necessary to run the simulations are daily precipitation, air temperature, shortwave radiation, relative humidity, and wind speed. For the Krycklan site, measurements from the Svartberg meteorological station $150 \mathrm{~m}$ southwest from the catchment outlet (elevation $10 \mathrm{~m}$ lower than the outlet) were used for the whole simulation period 2003-2013. For the first 2 years relative humidity and wind speed data were not available, and the long-term daily aver- 
age was used instead. For the Bruntland Burn, averaged data from two meteorological stations installed in the catchment, one at the valley bottom ( $10 \mathrm{~m}$ above catchment outlet) and one at the top of the catchment, on the southern hillslope ( $210 \mathrm{~m}$ above the outlet) were used from July 2014; prior to that data sets from weather stations in the neighbouring Girnock catchment were utilized as in previous model application for the site (Huijgevoort et al., 2016a), with the exception of shortwave radiation which was provided by the Centre for Environmental Data Analysis (MET Office, 2017). For Bogus, we used the meteorological station in the DCEW, $4 \mathrm{~km}$ southeast and roughly the same altitude as the catchment outlet. Occasional gaps were filled with other meteorological stations in the catchment, or snow telemetry (SNOTEL) meteorological station no. 978 (National Climatic Data Center, 2016) located $200 \mathrm{~m}$ north of the catchment top, $250 \mathrm{~m}$ above the catchment outlet. A spatially distributed environmental lapse rate of $-0.6{ }^{\circ} \mathrm{C} 100 \mathrm{~m}^{-1}$ was applied to air temperature measurements according to the moist adiabatic lapse rate (Goody and Yung, 1995). A +5.4\% $100 \mathrm{~m}^{-1}$ increase in precipitation was measured in the Bruntland along a hillslope covering $200 \mathrm{~m}$ elevation difference, and the parameter value was transferred to Bogus. We used temporally constant lapse rates, but they may vary in different seasons, latitudes, and orographic influences (Stone and Carlson, 1979; Sevruk and Mieglitz, 2002). Altitude effects are negligible for the gently sloping Krycklan site (Karlsen et al., 2016).

Streams for all experimental sites are gauged and quality controlled by the respective research groups and available online for Bogus and Krycklan (Laudon et al., 2013; Boise State University, 2017). Hourly or sub-hourly data were averaged to daily values. SWE in Krycklan was measured approximately $1 \mathrm{~km}$ west of the catchment in an open mire starting every midwinter and repeated at approximately 2-3week intervals until the snow had melted (Laudon and Löfvenius, 2016). SWE data representative of Bogus was acquired from the SNOTEL (same as for meteorological data) station where SWE is measured continuously with a pressure transducer (National Climatic Data Centre, 2016). The Bruntland does not have routine snow monitoring because of the unpredictability of the sporadic and highly transient snow influence. Streamflow and isotopes were used in the model calibration for all sites; SWE measurements for Krycklan and Bogus.

\subsection{STARR model setup}

The STARR model was first developed for the Bruntland Burn by Huijgevoort et al. (2016a), where full details can be found. Briefly, the hydrological part of the model conceptualizes soil and groundwater stores as linear reservoirs (Fig. 4) similar to the HBV model (Lindström et al., 1997). Previous, more lumped tracer-aided modelling in the Bruntland catchment (Birkel et al., 2011) was used as a basis to conceptualize the storing, mixing, and routing of tracers. In addition

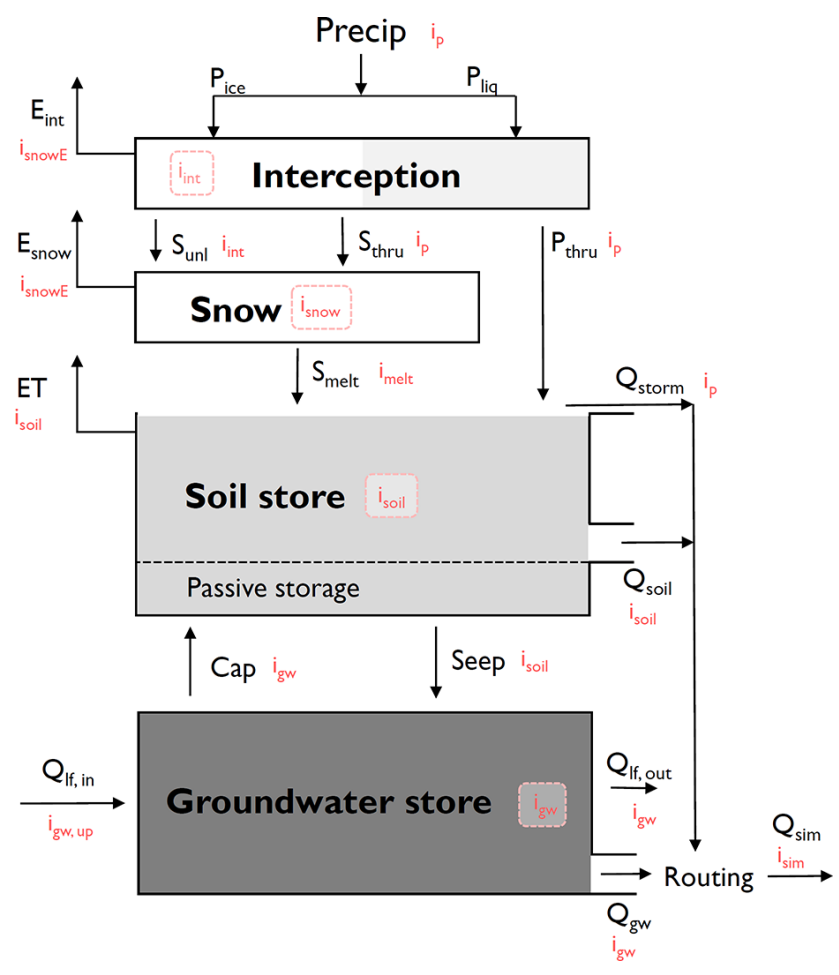

Figure 4. Schematic model structure of each model cell in STARR. Black arrows and boxes refer to water fluxes/storages, red i notation indicates the isotopic ratio of the given flux/storage. Calculation of variables and storages are presented in Appendix A1.

to routing and tracking water and tracer fluxes, the mixing equations were used to estimate water ages in the stream and different conceptualized hydrological compartments of the catchment (Soulsby et al., 2015) - a feature that was also implemented in STARR. Like its predecessors, the STARR model utilizes a concept of passive storage in isotopic mixing in the soil (Birkel et al., 2015). Passive storage parameterizes the water stored in the soil that does not relate to changes in discharge, but increases the total mixing volume of isotopes. The major development in the STARR model presented in van Huijgevoort et al. (2016a) was to spatially distribute the conceptual modelling equations to grid cells, so that each model cell has its own representation for the various storages and fluxes for both water and tracers in the conceptual model scheme (Fig. 4). Runoff fluxes from all cells are routed through the catchment to simulate the stream hydrograph and isotopic concentration. The approach allows presentation of transient water fluxes, storages, and water ages in a spatially explicit way in the landscape (for a visualization, see Huijgevoort et al., 2016b). The STARR model is built with a modular structure in the PCRASTER PYTHON framework (Karssenberg et al., 2010). Details for the model modules and related equations and parameters are given in Appendix A1 and Huijgevoort et al. (2016a), with the new developments of this study described below. 
STARR was developed with an overarching goal to keep the model simple and generically applicable (Huijgevoort et al., 2016a). The major advancement to STARR presented in this paper is to make it more suitable across northern latitudes by replacing the original degree-day snow module with an energy-driven process-based snow module with a novel capability to simulate isotopic evolution of the snowpack. The calculation routines that account for the "water" part of the model, ground snowmelt and accumulation, are based on formulations for single-layer snowpack energy and mass balance equations published in Wigmosta et al. (1994) and Walter et al. (2005), and described in detail in Ala-aho et al. (2017b). Energy balance for each time step is solved based on net radiation, latent and sensible heat, heat advection from precipitation, and heat storage in the snowpack. The energy balance is coupled with mass balance equations solving the amount of ice and liquid water retained in the snowpack and the snowmelt and sublimation fluxes. Model inputs for precipitation and air temperature are spatially distributed as described in Sect. 2.2, and the radiation terms are adjusted to the influence of slope, aspect, hillshading, and canopy sheltering. Tree canopy snow interception and unloading are simulated after Hedstrom and Pomeroy (1998). The isotopic ratio of the snowpack is linked to snowpack water balance simulations with the following assumptions and conceptualizations.

Isotopes in the snow storage (ground snowpack and interception storage) are fully mixed within each time step. The isotopic ratio of the remaining ground snowpack is solved with the mass balance equation

$$
\begin{aligned}
& i_{\mathrm{sn}_{j}}= \\
& i_{\mathrm{sn}(j-1)} \times \operatorname{SWE}_{(j-1)}+i_{\mathrm{P}_{j}} \times S_{\mathrm{thru}_{j}}+i_{\mathrm{P}_{j}} \times P_{\mathrm{liq}_{j}} \\
& \frac{+i_{\text {nt }_{j}} \times S_{\text {unl }_{j}}-i_{\text {snowE }_{j}} \times E_{\text {snow }_{j}}-i_{\text {melt }_{j}} \times S_{\text {melt }_{j}}}{\operatorname{SWE}_{(j-1)}+S_{\text {thru }_{j}}+P_{\text {liq }_{j}}} \\
& +S_{\text {unl }_{j}}-E_{\text {snow }_{j}}-S_{\text {melt }_{j}},
\end{aligned}
$$

where $j$ is simulation time step; SWE (mm) is snow water equivalent in the snowpack; $i_{\mathrm{P}}(\% o)$ is isotope ratio in the precipitation; $S_{\text {thru }}(\mathrm{mm})$ is throughfall bypassing interception storage; $P_{\text {liq }}(\mathrm{mm})$ is liquid precipitation; $i_{\text {int }}(\% o)$ is isotope ratio of snow interception storage; $S_{\text {unl }}(\mathrm{mm})$ is water unloaded from interception storage; $i_{\text {snowE }}(\%)$ is isotope ratio of sublimated water from Eq. (1); $E_{\text {snow }}(\mathrm{mm})$ is amount of simulated snow sublimation; $i_{\text {melt }}(\% o)$ is isotope ratio of snowmelt from Eq. (2); and $S_{\text {melt }}(\mathrm{mm})$ is amount of snowmelt.

Snow sublimation fractionates the water on the ground and the intercepted snow storage, leaving the remaining snow enriched in heavy isotopes. This is achieved by introducing an offset parameter $E_{\text {frac }}$ to determine the level of depletion in the sublimated water relative to the snowpack:

$i_{\text {snowE }}=i_{\text {sn }}-E_{\text {frac }}$,

where $i_{\text {snowE }}(\% o$ ) is isotope ratio of the sublimated water; $i_{\text {sn }}(\% o)$ is isotopic concentration of the snowpack, and $E_{\text {frac }}$
$(\%)$ is offset parameter. $E_{\text {frac }}$ is calibrated and allowed to take values between 0 and $15 \%$ based on the equilibrium difference of $15 \%$ o between ice and vapour isotopic ratio at $0{ }^{\circ} \mathrm{C}$ temperatures (Ellehoj et al., 2013).

Water leaving the snowpack is initially depleted in heavy isotopes with respect to the snowpack, and the snowmelt water grows progressively more enriched as the snowmelt advances. The empirical formulation in Eq. (3) is proposed in order to mimic the gradual isotopic enrichment of both snowmelt runoff and snowpack over the overall melt period, which is frequently observed in field studies (Taylor et al., 2002) and theoretically shown in modelling experiments (Feng et al., 2002):

$i_{\text {melt }}=i_{\text {sn }}-\frac{M_{\text {frac }}}{d_{\text {melt }}}$,

where $i_{\text {melt }}(\% o$ ) is the isotope ratio of the snowmelt water, $M_{\text {frac }}(\% o)$ is the offset parameter, and $d_{\text {melt }}$ is the number of days snowpack has experienced snowmelt. $M_{\text {frac }}$ is calibrated and allowed to take values between 0 and $3.5 \%$ based on the equilibrium difference of $3.5 \%$ o between ice and liquid water isotopic ratio. Using the equation, the first melt event is offset by the value of parameter $M_{\text {frac }}$ (the value for $d_{\text {melt }}$ being 1 ), and with subsequent snowmelt days the offset approaches 0 with increasingly higher values for $d_{\text {melt }}$.

For full details how SWE, $S_{\text {thru }}, S_{\text {uln }}, E_{\text {snow }}$, and $S_{\text {melt }}$ are simulated, the reader is referred to Ala-aho et al. (2017b) where the snow routine algorithms are provided with a modelling experiment to demonstrate the snow algorithm functionalities and a field test of the model performance is done against snowmelt lysimeter data. The new process-based energy balance snow module is embedded in STARR similarly to the previous degree-day module, providing water and isotope influx to soil storage. Snow age is tracked according to Eq. (1) but replacing the isotope ratios with water ages in all storages and fluxes. Water age of incoming precipitation is taken as 1 , and the sublimation and melt fractionation processes do not alter snow age. With the full-mixing assumption, water stored as snow is aged while the snowpack persists, but this is refreshed with new snowfall, weighted by snow amount. Water entering the catchment during snowmelt will therefore be reasonably approximated as having an age younger than the full snow-covered season, but considerably older than only the most recent snowfall. Therefore, the snowmelt entering the catchment is typically older than precipitation, depending on the length of season of snow coverage.

A second modification was to reformulate the soil storage parameterization and to change the storage-discharge conceptualization from a linear reservoir into a power law (Eq. A12). The concept of field capacity also is changed from Huijgevoort et al. (2017a), where the field capacity (FC) was defined as the maximum amount of water that could be stored in the linear soil storage (SM), whereas now we conceptualize this - as more typically done in soil physics 
- as the amount of water that is preferably retained in the soil, defined by parameters for volumetric field capacity and soil depth (Eq. A9), both technically measurable in the field. These changes were done to create a more physically based parameterization for the model and to allow nonlinear seepage and outflow processes with high soil storage values. The need for adaptation became apparent when applying the original model algorithms to Krycklan and Bogus. In its original formulation the model did not allow for high enough seepage rates from the soil to groundwater domain as observed in Bogus, or nonlinearly increased runoff generation from the soil domain during times of high soil storage, also known as the transmissivity feedback, present in Krycklan.

Finally, in contrast to previous work, here we assumed the evaporation age to be equal to the water age in the soil storage. In the previous model implementation in Huijgevoort et al. (2016a), the simulated soil water age was affected by evaporation, but the simulated isotope composition of the soil was not; as a result the simulated evaporation age was not informed/constrained by the isotope model calibration and in this study it was excluded to simplify the model. Re-incorporating evaporated water age in the simulations would benefit from vertically layered soil parameterization and from explicit hydrological partitioning between evaporation and transpiration (see e.g. Sprenger et al., 2016a).The mathematical formulations of the core functions of the STARR model with the soil model alterations explained above are given in Appendix A1 and (Huijgevoort et al., 2016a).

\subsection{Model parameterization and calibration}

We used the Monte Carlo approach in model calibration and carried out 10000 simulations for each experimental site to test the model performance with varied parameter sets. We used random sampling of the parameter space assigning uniform distribution for all parameters, with pre-defined parameter ranges (minimum and maximum parameter value) given in Table 1. The model was run 10000 times, each run with a different, randomly sampled parameter set. Because some of the parameters were not measurable in the field or could not be estimated from the literature, we did a series of preliminary simulations for all sites to find appropriate sampling ranges for these parameters.

For the snow module we included four parameters in the Monte Carlo calibration (Table 1): correction coefficient for undercatching snowfall $\left(c_{\text {corr }}\right)$, threshold temperatures for precipitation phase $\left(\mathrm{TT}_{\text {low }}\right.$ below which all rain is considered as snow and $\mathrm{TT}_{\text {high }}$ above which all rain is considered as liquid), and an empirical coefficient for decreasing snow albedo for ageing snowpacks $\left(a_{\text {pow }}\right)$. For details about the calibrated parameter see Appendix A1 and for the equations for the energy-balance-based snow module see Ala-aho et al. (2017b).
Table 1. Calibrated parameters and parameter ranges. For Bruntland, some of the soil parameters were split into hillslopes (h) and valley bottom (v), for Krycklan between forest (f) and mire (m). For parameters which were sampled over orders of magnitudes, the parameter was log-transformed in the sampling process, which is indicated by $(\log )$.

\begin{tabular}{|c|c|c|c|}
\hline Parameter & Eq. & Min & $\operatorname{Max}$ \\
\hline \multicolumn{4}{|l|}{ Snow } \\
\hline$c_{\text {corr }}(-)$ & (A3) & 0 & 0.3 \\
\hline $\mathrm{TT}_{\text {low }}\left({ }^{\circ} \mathrm{C}\right)$ & (A1) & -2 & 0 \\
\hline $\mathrm{TT}_{\text {high }}\left({ }^{\circ} \mathrm{C}\right)$ & (A1) & 0 & 2 \\
\hline$a_{\text {pow }}(-)$ & (A5) & 1 & 3 \\
\hline \multicolumn{4}{|l|}{ Isotopes } \\
\hline$E_{\text {frac }}(\% o)$ & (2) & 15 & 0 \\
\hline$M_{\text {frac }}(\% o)$ & (3) & 3.5 & 0 \\
\hline $\mathrm{SM}_{\text {pas }}(\mathrm{mm})$ & (A20) & 50 & 300 \\
\hline \multicolumn{4}{|l|}{ Soil and groundwater } \\
\hline$S_{\mathrm{d}}(\mathrm{m})$ & (A7) & & \\
\hline Bogus & & \multicolumn{2}{|c|}{ map, not varied } \\
\hline Krycklan & & $\mathrm{f}: 0.5 \mathrm{~m}: 0.2$ & $\mathrm{f}: 1.0 \mathrm{~m}: 0.5$ \\
\hline Bruntland & & v:0.1 h:0.5 & $\mathrm{v}: 0.5, \mathrm{~h}: 1$ \\
\hline$\beta_{\text {seep }}(-)$ Bogus only & (A8) & 1 & 10 \\
\hline$\beta_{\text {pow }}(-)$ Bogus only & (A8) & 1 & 3 \\
\hline$k_{\mathrm{S}}\left(\right.$ day $\left.^{-1}\right)$ & (A10) & & \\
\hline Bogus (log) & & 1 & 50 \\
\hline Krycklan & & $\mathrm{f}: 5, \mathrm{~m}: 5$ & $\mathrm{f}: 20, \mathrm{~m}: 20$ \\
\hline Bruntland & & $\mathrm{v}: 5, \mathrm{~h}: 5$ & $\mathrm{v}: 50, \mathrm{~h}: 50$ \\
\hline$k_{\text {pow }}(-)$ & (A10) & & \\
\hline Bogus and Krycklan & & 1 & 3 \\
\hline Bruntland & & 1 & 4 \\
\hline$k_{\mathrm{g}}(\log )$ & (A15) & $1 \mathrm{E}-5$ & $1 \mathrm{E}-3$ \\
\hline
\end{tabular}

For the soil module we included parameters influencing the amount of potential storage in the soil $\left(S_{\mathrm{d}}\right)$, and parameters $\left(k_{\mathrm{s}}\right.$ and $\left.k_{\text {pow }}\right)$ controlling the amount of outflow from the soil storage $\left(Q_{\text {soil }}\right)$. For the Bogus site, seepage from soil to groundwater storage proved an important process. Therefore, parameters controlling seepage ( $\beta_{\text {seep }}$ and $\left.\beta_{\text {pow }}\right)$ were included as calibrated parameters. For field capacity and porosity we used site-specific parameter values based on prior research in the catchments (Nyberg et al., 2001; $\mathrm{McNa}$ mara et al., 2005; Ala-aho et al., 2017a). For Bogus, we used a soil depth map derived for the whole DCEW (Tesfa et al., 2009) for spatially distributed soil depth values. The organic soils for the riparian peatlands in Bruntland and Krycklan were parameterized according to Päivänen (1973) in terms of porosity and field capacity (FC). For the groundwater, one parameter $\left(k_{\mathrm{g}}\right)$, which linearly relates the groundwater storage to groundwater outflow $\left(Q_{\mathrm{gw}}\right)$, was calibrated.

Finally, three parameters affecting the routing of isotopes were included in the calibration: $E_{\text {frac }}$ setting the offset between sublimated and remaining isotopic ratio in the snowpack (see Eq. 2), $M_{\text {frac }}$ regulating the isotopic fractionation 
between snowmelt water and snowpack, and $\mathrm{SM}_{\text {pas }}$ representing an additional mixing volume in the soil storage required to dampen the isotopic variability of the soil water.

Initial conditions for the Monte Carlo model runs at each site were established by looping the input data until the storages and water ages appeared to plateau at a constant level. State variables (water storages, isotope ratios, water ages) in the groundwater module were the only variables with high storage values which were not reset during the annual water cycle, and therefore most influenced by the looping. The spatially distributed values for groundwater storage, isotope ratios, and water ages received after the looping were used as initial conditions in the subsequent Monte Carlo runs. For each individual Monte Carlo model run, a spin-up period of 1 year was used for Bruntland and Krycklan, and of 2 years for Bogus, to reduce the impact of initial conditions on the calibration period. For Bruntland, we looped climate data for the first year of the simulation for spin-up input. For Krycklan and Bogus, we used the climate data from previous years. A 2-year period was used in Bogus because the initial storages were greater and therefore stabilizing the storages at the beginning of each Monte Carlo run was considered to take a longer time.

During the model optimization we wanted to keep the calibration setup and objective functions identical across catchments to make the results comparable. We used a single goodness-of-fit (GOF) metric for each observationsimulation pair (streamflow, isotope ratios, SWE) to differentiate between rejected model runs and those accepted as "behavioural". The Kling-Gupta efficiency (KGE, Eq. 4) was selected as GOF for streamflow and SWE and mean absolute error (MAE; Eq. 5) for the isotope ratios:

$$
\begin{aligned}
\mathrm{KGE} & =1-\sqrt{(r-1)^{2}+\left(\mu_{\mathrm{s}} / \mu_{\mathrm{o}}-1\right)^{2}+\left(\sigma_{\mathrm{s}} / \sigma_{\mathrm{o}}-1\right)^{2}}, \\
\mathrm{MAE} & =\frac{\sum_{i=1}^{N}\left|s_{i}-o_{i}\right|}{N},
\end{aligned}
$$

where $r$ is the Pearson correlation coefficient; $\mu$ is the mean; $\sigma$ is the standard deviation; subscripts "s" and "o" refer to simulated and observed values, respectively; and $N$ is the number of simulation-observation pairs.

Kling-Gupta efficiency was used because it combines several measures of misfit between observations and simulations (correlation, bias, and a measure of relative variability; first, second and third term inside the square root in Eq. 4, respectively) into a single number in a more robust way than the frequently used Nash-Sutcliffe efficiency (NSE) performance metric (Gupta et al., 2009). Additionally, the NSE puts a primacy on simulation of high flows, whereas, for a hydrological model to accurately and simultaneously capture isotope dynamics across the flow regime, a more balanced GOF measure for stream flows is needed as shown in other studies (e.g. Birkel et al., 2015). MAE was used for the isotopes because it focuses on minimizing the bias between observations and simulations and the relatively low number of stream isotope samples in Bogus did not allow us to use a measure placing emphasis on variability and correlation. In addition, MAE gives an intuitive number of typical prediction error easily comparable to, for example, the analytical error of the isotope ratio. The selected GOF metric ultimately remains a subjective choice in any model calibration, but with the considerations above we found that the selected metrics facilitated convenient and robust comparison between catchments.

From the ensemble of 10000 model runs, the 100 "best" runs were identified using the cumulative distribution function (CDF) of the GOF measures with the following logic: each parameter set, and the resulting simulation output, maps a value on the CDF of the GOF measure for all three calibration variables (KGE for streamflow and SWE; MAE for isotope ratios). We determined a threshold quantile in the GOF CDF's above which the GOF from exactly 100 runs in all calibration targets were mapped using

$$
\begin{aligned}
& \left.F_{X_{\mathrm{f}}}\left(x_{\mathrm{f}}\right)=P\left(\mathrm{GOF}_{\mathrm{f}} \geq x_{\mathrm{f}}\right)=n_{\mathrm{run}}\right), \\
& \left.F_{X_{\mathrm{i}}}\left(x_{\mathrm{i}}\right)=1-P\left(\mathrm{GOF}_{\mathrm{i}} \leq x_{\mathrm{i}}\right)=n_{\mathrm{run}}\right), \\
& \left.F_{X_{\mathrm{s}}}\left(x_{\mathrm{s}}\right)=P\left(\mathrm{GOF}_{\mathrm{s}} \geq x_{\mathrm{s}}\right)=n_{\text {run }}\right),
\end{aligned}
$$

where subscripts "f", " $\mathrm{i}$ ", and "s" represent flow, isotope, and snow, respectively; $F_{X}(\mathrm{x})$ is the threshold quantile; GOF is the goodness of fit measure; $n()$ is the number of GOF samples located above (or below in Eq. 7) the GOF value $x$ in the CDF; $n_{\text {run }}$ is the specified number of runs (in our case 100). Values for $x_{\mathrm{f}}, x_{\mathrm{i}}$, and $x_{\mathrm{s}}$ were obtained using an iterative algorithm that satisfies $F_{X_{\mathrm{f}}}\left(x_{\mathrm{f}}\right)=F_{X_{\mathrm{i}}}\left(x_{i}\right)=F_{X_{\mathrm{s}}}\left(x_{\mathrm{s}}\right)$ when $n_{\text {run }}=100$, in a way that maximizes the $F_{X}(x)$.

To clarify the calibration procedure with an example, let us consider two GOF measures, KGE of streamflow and SWE, to constrain the selection of 100 behavioural simulations from an ensemble. In this case it is unlikely, although possible, that the same 100 simulations that produce the highest GOF values for streamflow would also have the highest GOF values for SWE. To find the threshold quantile above which the GOF from exactly 100 runs in both calibration objectives map, first an initial guess is made; we used $F_{X_{\mathrm{f}}}\left(x_{\mathrm{f}}\right)=F_{X_{\mathrm{s}}}\left(x_{\mathrm{s}}\right)=0.5$, which corresponds to the median of GOF values for $x_{\mathrm{f}}$ and $x_{\mathrm{s}}$, streamflow and SWE, respectively. With this quantile as a threshold it is checked how many individual simulations produce GOF values that are higher than $x_{\mathrm{f}}$ and $x_{\mathrm{s}}$ for both streamflow and SWE, respectively. If the number of simulations above the $x_{\mathrm{f}}$ and $x_{\mathrm{S}}$ GOF thresholds in both objectives is higher than the preassigned number $n_{\text {run }}$ (in our case 100), a step up the CDF is taken, by adding a small increment in the threshold quantile, for example: $F_{X_{\mathrm{f}}}\left(x_{\mathrm{f}}\right)=F_{X_{\mathrm{s}}}\left(x_{\mathrm{s}}\right)=0.51$. hen the number of simulations which exceed KGE value for both streamflow and SWE ( $x_{\mathrm{f}}$ and $x_{\mathrm{s}}$, respectively) are again counted for the updated threshold, and the process is repeated, until a quantile $F_{X_{\mathrm{f}}}\left(x_{\mathrm{f}}\right)=F_{X_{\mathrm{s}}}\left(x_{\mathrm{s}}\right)$, for which $n_{\mathrm{run}}=100$ is reached. The re- 

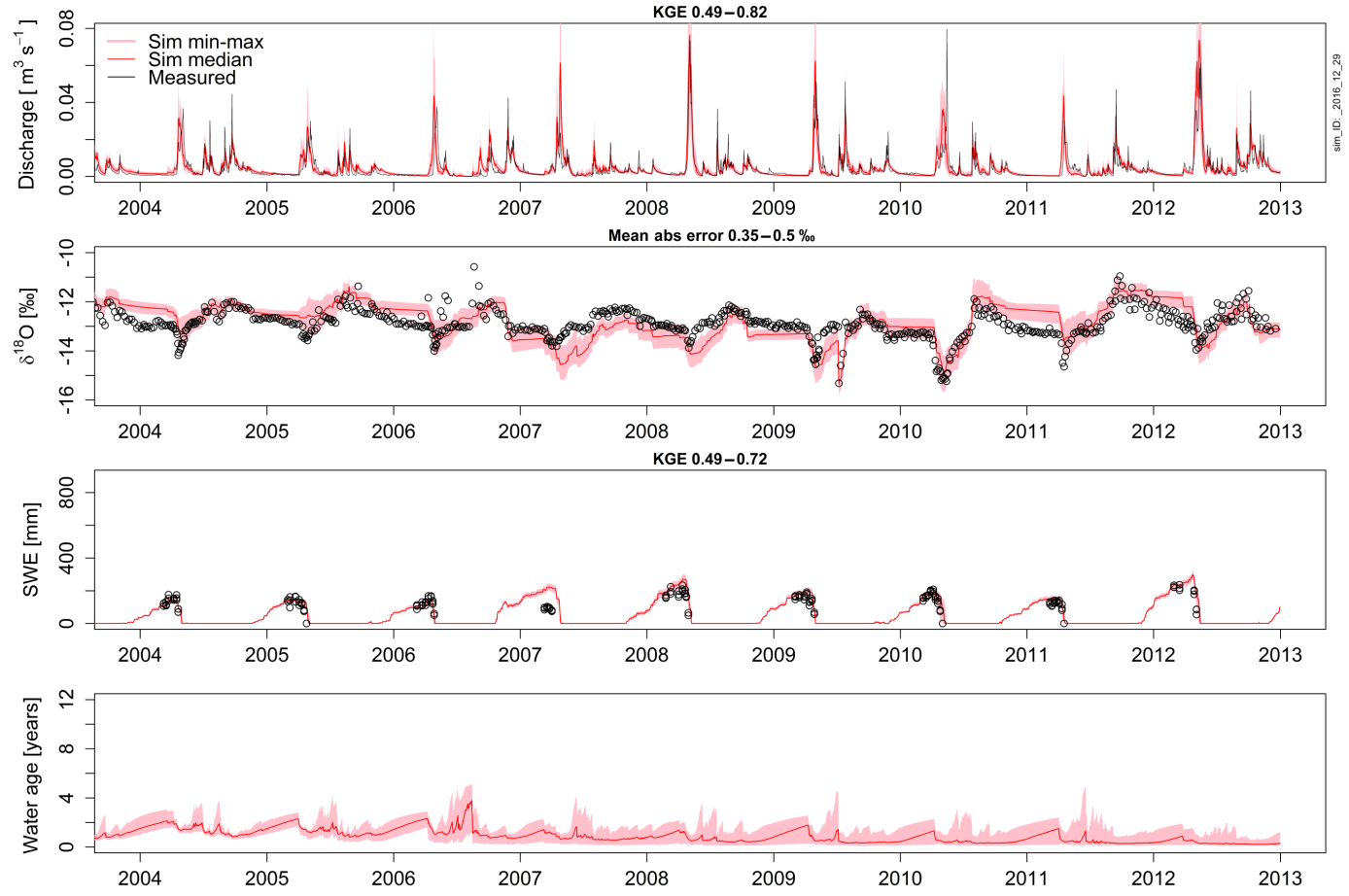

Figure 5. Krycklan C7 simulation output: top panel shows the streamflow, second panel the isotope ratio at the stream outlet, third panel the SWE, and lowest panel the simulated stream water age. GOF measures are shown on plot titles.

sulting threshold GOF value $x_{\mathrm{f}}$, in this example measured in $\mathrm{KGE}$, will be lower than if constrained by flow data alone, because some simulations producing a good KGE for flows will be rejected as they have a $\mathrm{GOF}_{\mathrm{f}}<x_{\mathrm{s}}$ for SWE.

Because for the KGE high numbers indicate a good model fit whereas for MAE low numbers indicate a good fit, for the isotope fit the threshold MAE quantile was calculated as $1-F_{X}(x)$. For Bruntland, only Eqs. (6) and (7) were used because SWE data were not available and snowmelt rarely dominates the hydrograph. The simulations for which GOF measures were above (below for MAE) the threshold in all calibration objectives were retained as the 100 best behavioural runs. Reported ranges for the GOF measured are obtained using $\left[F_{X}^{-1} \min \left(x_{\text {ret }}\right), F_{X}^{-1} \max \left(x_{\text {ret }}\right)\right]$, where $x_{\text {ret }}$ is the array of quantiles of the retained runs. The introduced approach allows us to prespecify the number of behavioural runs while circumventing the need to combine the GOF metrics into a single objective function (e.g. Huijgevoort et al., 2016a). When a single objective function is constructed from multiple GOF metrics, it is often difficult to combine GOF metrics that need to be maximized (such as KGE) and minimized (such as MAE) in the model calibration. Our approach is based on quantiles of the GOF metric rather than its numerical value, making the method convenient in combining metrics that are to be minimized or maximized, or have different ranges of numerical values.

We explored the sensitivity of parameters involved in the behavioural runs by calculating the ratio between pre- and post-calibration standard deviation of the parameter values. If the parameters for behavioural runs occupy a smaller range than the sampled parameter values (range approximated as standard deviation), this will result in a ratio of less than 1 . We used this ratio as a simple proxy for parameter sensitivities in order to identify the most sensitive parameters and to compare parameter sensitivities across catchments. A similar sensitivity analysis for each site was done prior to the final calibration runs in order to exclude insensitive parameters from the calibration and to look for suitable ranges for the sensitive ones.

\section{Results}

\subsection{Simulation of time series of streamflow, stream isotope ratios, $\mathrm{SWE}$, and water ages}

The model is able to produce a good fit to all calibration objectives - that is streamflow, stream isotope ratios, and SWE - for all three catchments (Figs. 5, 6 and 7). For the three sites, the GOF metrics for streamflow KGE range between 0.5 and 0.8 and MAE in stream isotopes ranges between 0.3 and $0.5 \%$.

For Krycklan (Fig. 5.), fits for the streamflows span KGE values from 0.49 to 0.82 . In general, low flows are matched very well, as well as the timing and magnitude of snowmeltinduced runoff. The only notable bias is that the flow peaks 

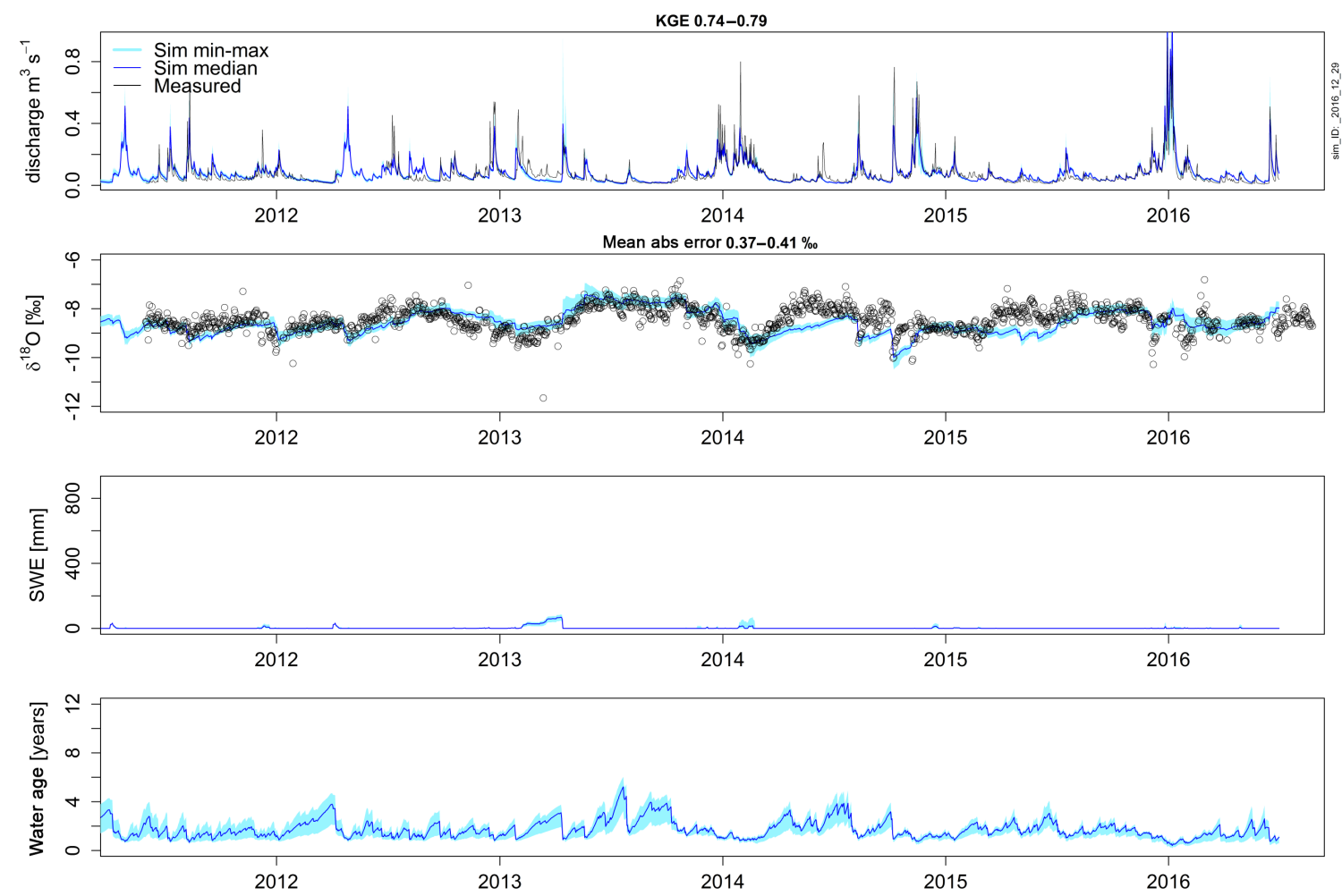

Figure 6. Bruntland Burn simulation output: top panel shows the streamflow, second panel the isotope ratio at the stream outlet, third panel the SWE, and the lowest panel the simulated stream water age. GOF measures are shown on plot titles.

during summers are not always fully captured. The model reproduces both the stream isotopic depletion due to snowmelt and summer enrichment caused by more enriched rainfall with good accuracy, and the absolute error $(0.35-0.5 \%$ ) is close to the analytical accuracy of $0.2 \%$. The most consistent bias is seen during winter, when the simulations are not able to capture the gradual depletion of stream isotopes. Snow amounts are simulated reasonably well with KGEs up to 0.72 , with the exception of winter 2007. Failure to simulate the amount of accumulated snow has immediate consequences producing poor fits also for streamflow and stream isotopes. Simulated water ages show seasonality with progressively ageing water during the winter $(\sim 2-3$ years $)$, a decrease in age ( $\sim 1-2$ months) during snowmelt, and greater variability during the summer, with water sources being a mix of older water from groundwater storage and younger water entering and exiting the soil storage during and after storm events.

Streamflow for Bruntland Burn (Fig. 6) is generally well captured for both dry and wet seasons with consistently high KGEs between 0.74 and 0.79 . A similar problem as in Krycklan seems to occur and the magnitudes of some of the largest events are underestimated. Simulations of $\delta^{18} \mathrm{O}$ capture the more gradual trends of depleted winters and enriched summers, with a consistently low absolute error $(0.31-0.41 \%)$, though some more marked isotope excur- sions in larger events (e.g. winter of 2015/2016) are underestimated. Snow influence, when plotted for comparative purposes in the same scale as the other experimental catchments, is minor, but still present in some winters, and the flows of melt events (e.g. in winter of 2012/2013) are captured. Stream water ages in Bruntland are more strongly influenced by seasonality in precipitation with virtually no snowmelt influence. Oldest ages ( $\sim 4-5$ years) occur during dry summer periods, particularly prominent in 2013 and 2014. Wetter winter periods seasons result in windows of younger water dominance ( $\sim 2-6$ months) at high flows, as seen in 2013/2014 and 2015/2016. However, large summer events can have similar younger waters.

The hydrological regime of Bogus (Fig. 7) is heavily dominated by the spring and occasional midwinter snowmelt, with very little variability in flow during dry and hot summers. These dynamics are markedly different from the other two catchments, and are adequately reproduced by the model with KGEs between 0.56 and 0.78 . The low variability in the stream isotope response is for most parts enveloped by the model outputs, with a slightly higher range for absolute error than for the two other sites $(0.27-0.64 \%$ o). Due to the lower number of streamflow and precipitation isotope samples, the tracer time series has less power in constraining the model, reflected in higher uncertainties around isotopes and water ages. Dynamics of snow accumulation and melt are 

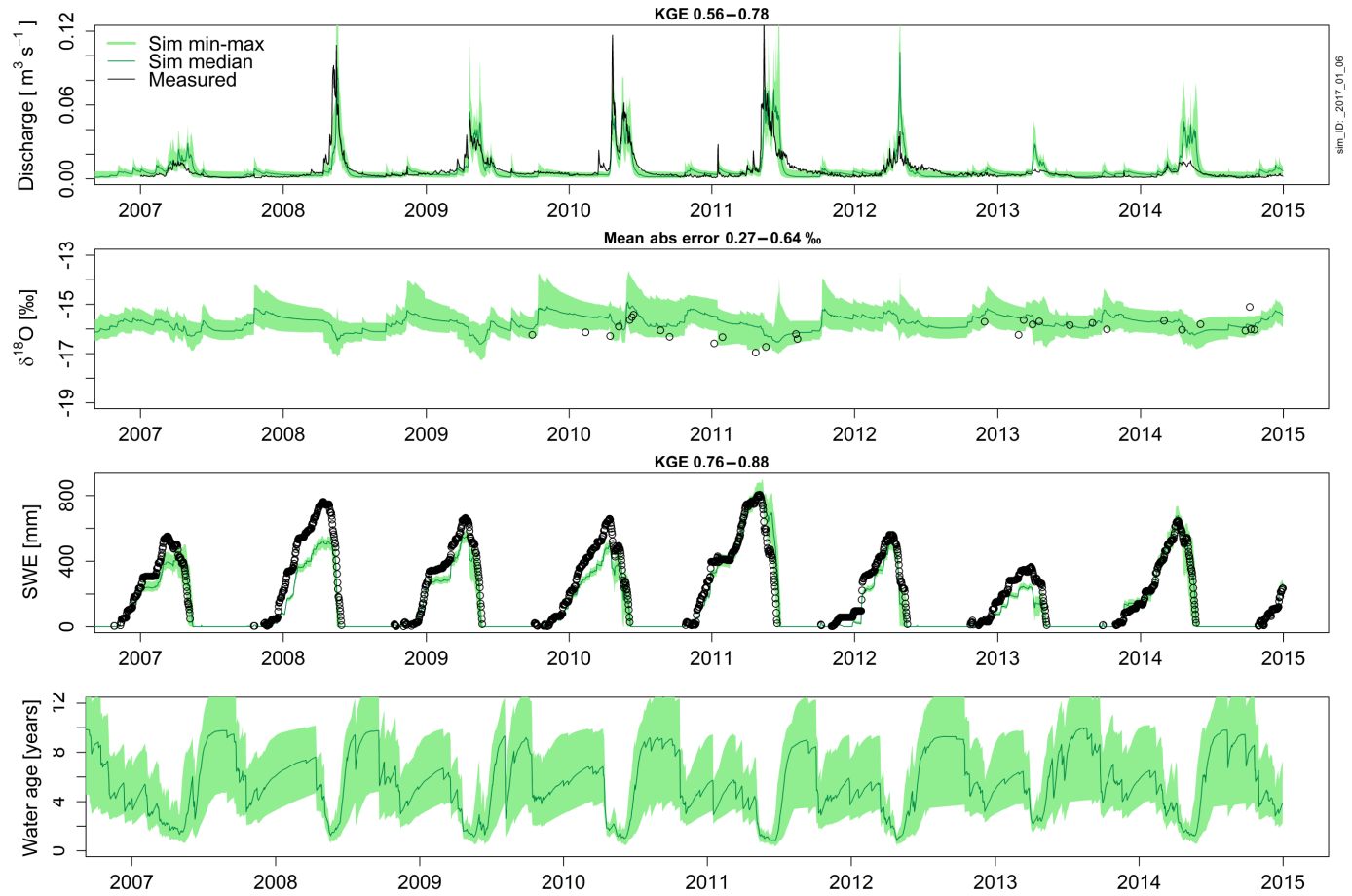

Figure 7. Bogus Creek simulation output: top panel shows the streamflow, second panel the isotope ratio at the stream outlet, third panel the SWE, and lowest panel the simulated stream water age. GOF measures are shown on plot titles.

well captured (KGEs between 0.76 and 0.88), though there is a tendency to underestimate the snow amount. Simulated water ages are considerably older than for the other two catchments. The age is reduced annually most significantly by the snowmelt but only down to $0.5-1$ years (while in Krycklan and Bruntland the ages are in ranges of weeks and months, respectively), followed by a baseflow period in the summer with older water ( $>10$ years) simulated from the groundwater storage. Autumn rainfalls again reduces the water age, from where the ages are occasionally refreshed by midwinter snowmelt events, as for example in winter of 2010/2011.

\subsection{Simulated water ages - comparison of spatial distribution and PDFs between catchments}

The PDFs of the simulated water ages (best 100 runs, Fig. 8) for Krycklan and Bruntland show a similar age distribution skewed towards younger waters. Water ages in Krycklan are younger than in Bruntland with a modal water age $\sim 3$ months and younger median age $(<1$ year $)$. In Bruntland, the stream water age distribution shows less kurtosis with a mode of $\sim 14$ months and median age of $\sim 1.5$ years. The water age distribution for Bogus is very different from the other two with a flatter and wider distribution and older median age of $\sim 5$ years with a largely missing young water (<0.5 year) component.

The spatial distribution of the water ages for dry and wet conditions are demonstrated in Fig. 9 and through an ani-

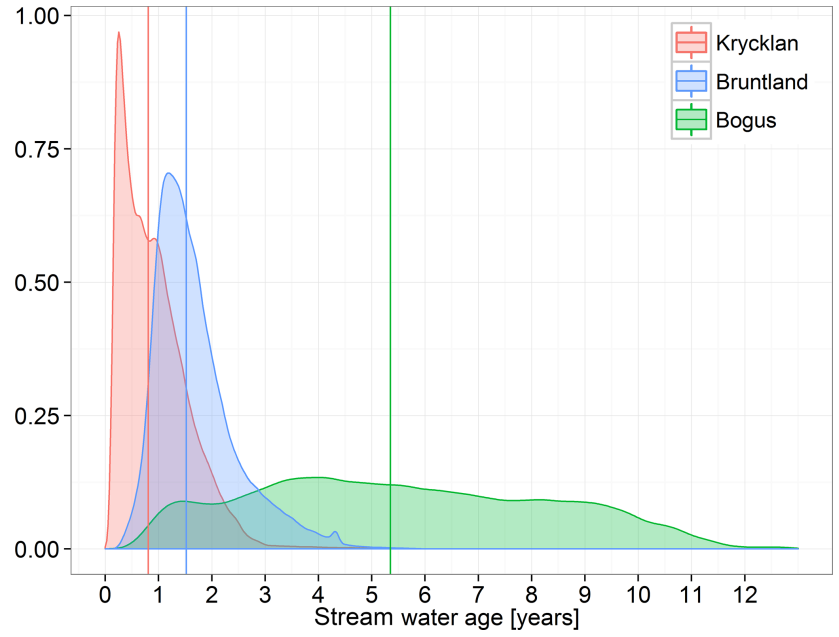

Figure 8. Probability density functions of the simulated water ages for the best 100 runs for all three catchments. The vertical lines mark the median age in each catchment.

mation (Supplement S1). First looking into the water ages across catchments in dry conditions (top row in Fig. 9), water in Krycklan is typically younger than 1.5 years, with older water ( $>2$ years) primarily focused in near topographical lows where older water accumulates because of converging groundwater flow. In Bruntland there is a separation between young water $(<1.5$ years $)$ on the hillslopes and old water 
( $>4$ years) in the valley bottom areas. In Bogus the water age is predominantly $>4$ years, except for some individual cells with low storage on local topographic highs. Comparing the spatial distribution of water age during wet conditions (bottom row in Fig. 9), Krycklan experiences the smallest change visually, mainly because the water throughout the catchment was relatively young to start with. In Bruntland there is a substantial decrease in age for both hillslopes (down to $<0.5$ years) and valley bottom $(<1.5$ years). In Bogus water age is brought down in areas with young water input from snowmelt - in the particular snapshot above elevation $120 \mathrm{~m}$ from the outlet (compare with Fig. 1).

The intimate relationship between spatial distribution of runoff and water age is best seen in the animation provided in the Supplement (S1). The animation shows for each model cell its water age (top row) and runoff (middle row), and the simulated stream hydrograph at the outlet (bottom row). Simulations span 1 calendar year and a typical hydrological year is shown for each catchment (2008-2009 for Krycklan, 2014-2015 for Bruntland and 2011-2012 for Bogus). A threshold of $0.1 \mathrm{~mm}$ for runoff is selected to highlight the spatial variability in runoff generation. The temporal variability in both water age and runoff demonstrates the dominant snow influence in Krycklan and Bogus in terms of producing larger fluxes of young water to the streams. The main difference between the two catchments is that in Krycklan snowmelt takes place at the same time in the entire catchment over a period of 3 weeks, while in Bogus the snowmelt proceeds from lower to higher elevations over a period of almost 2 months. Both catchments show only minor variability in water age and runoff outside the snowmelt period. In Bruntland, the spatially distributed response is driven by rainfall events throughout the year. This is seen by constantly expanding and contracting areas of runoff generation and a refreshing of the water age in the valley bottom due to rainfall events.

The simulated storages in soil and groundwater (Table 2) provide an explanation for the differences between simulated water ages in the catchments. The median values for storages are almost an order of magnitude higher between Krycklan $(64 \mathrm{~mm})$ and Bruntland $(540 \mathrm{~mm})$ and Bogus $(2182 \mathrm{~mm})$, with median ages increasing by the same order. Differences in soil storage are much lower and for Krycklan and Bruntland in particular help explain the dominance of younger waters at high flows due to the limited mixing potential in groundwater storage. At Krycklan passive soil storage dominates the isotope mixing over water storage soil and groundwater. At Bruntland the mixing volumes in passive storage and soil and groundwater are approximately equal in magnitude, whereas at Bogus mixing volume available in the groundwater store greatly exceeds the soil and passive storage.
Table 2. Simulated catchment average storages in groundwater storage, soil storage (water), and passive soil storage (isotope mixing) for experimental catchments in the 100 behavioural runs. Range of storage is shown as $0.25-0.75$ percentile of medians to demonstrate typical ranges in behavioural simulations.

\begin{tabular}{lrrr}
\hline Site & Krycklan & Bruntland & Bogus \\
\hline GW storage median $(\mathrm{mm})$ & 63 & 540 & 2182 \\
range $(\mathrm{mm})$ & $(36-128)$ & $(450-607)$ & $(1791-2570)$ \\
Soil storage median $(\mathrm{mm})$ & 31 & 61 & 42 \\
range $(\mathrm{mm})$ & $(25-36)$ & $(54-66)$ & $(35-50)$ \\
Passive storage median $(\mathrm{mm})$ & 257 & 261 & 186 \\
range $(\mathrm{mm})$ & $(229-276)$ & $(216-287)$ & $(122-236)$ \\
\hline
\end{tabular}

\subsection{Parameter sensitivities}

Based on the sensitivity analysis (Fig. 10) a number of the model parameters can be interpreted as insensitive for all sites, namely those controlling snowfall threshold temperatures $\left(\mathrm{TT}_{\text {low }}\right.$ and $\left.\mathrm{TT}_{\text {high }}\right)$, snowmelt fractionation $\left(M_{\text {frac }}\right)$, and soil depth $\left(S_{\mathrm{d}}\right)$. For other parameters, the sensitivities vary between sites depending on the dominant runoff generation processes. For the catchments with a strong snow influence and SWE data included in the calibration, i.e. Krycklan and Bogus, parameters related to snow sublimation fractionation $\left(E_{\text {frac }}\right)$, correction coefficient for snowfall $\left(c_{\text {corr }}\right)$, and the parameter for an ageing snow albedo $\left(a_{\text {pow }}\right)$ demonstrate sensitivity. Passive storage for isotope mixing volumes in the soil $\left(\mathrm{SM}_{\mathrm{pas}}\right)$ is sensitive for Bruntland and Krycklan where outflow from soil storage plays an important role in isotope simulation, but not that important for the GW-dominated Bogus.

For parameters controlling the outflow from soil storage, $k_{\mathrm{s}}$ and $k_{\mathrm{pow}}$, there appears to be a trade-off in sensitivity for all sites: if the one is sensitive, the other shows less sensitivity. The parameter relating groundwater flux to storage $k_{\mathrm{g}}$ is sensitive for the sites with larger GW storage (Bruntland and Bogus), but not so much at Krycklan with less groundwater storage (see also Table 2).

\section{Discussion}

\subsection{Simulations of streamflow, stream isotopes, and snow in northern headwaters}

This study demonstrates the flexibility and generality of the STARR modelling framework now advanced for snowmelt isotope routines to facilitate simulations in northern snowinfluenced catchments. Correctly representing snow and runoff generation processes in northern catchments is important in hydrological modelling and will be increasingly important with a warming climate and following changes in cryogenic processes (Barnett et al., 2005; Berghuijs et al., 2014). Our results show reasonable performance in terms of GOF metrics. The streamflow KGE was around 0.6-0.8, 


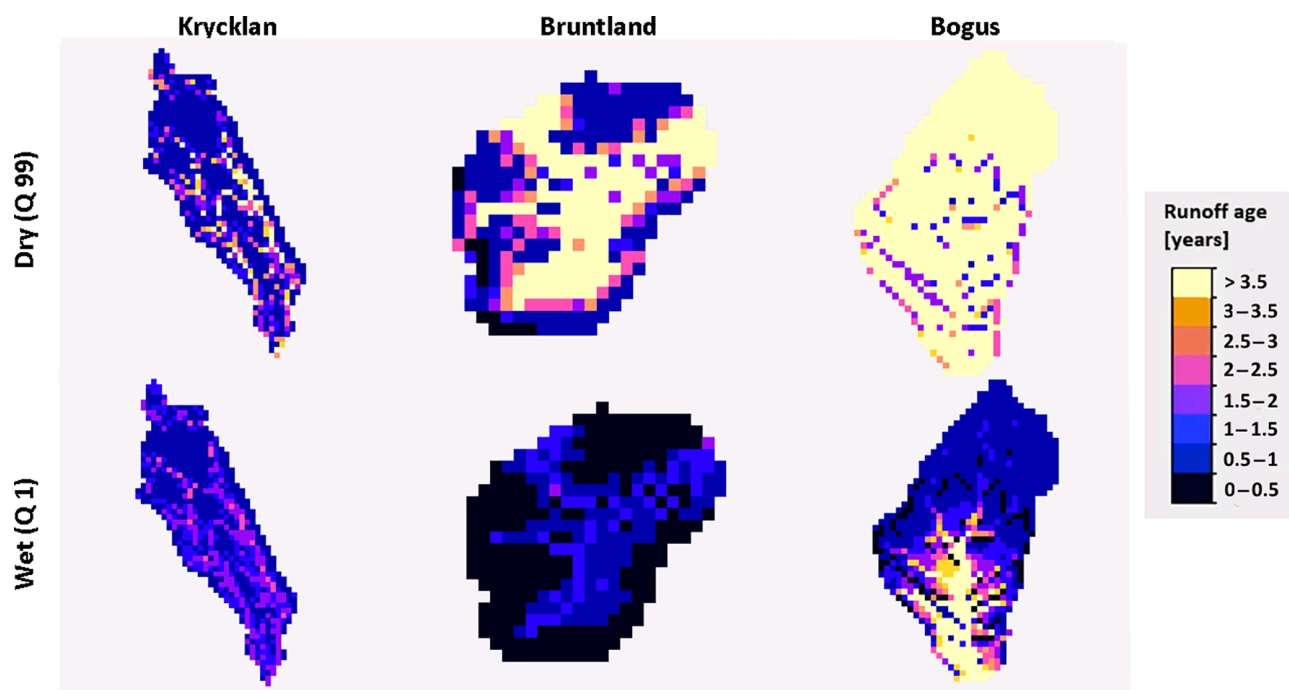

Figure 9. Spatial distribution of water age in each catchment for dry (1\% quantile) and wet (99\% quantile) conditions. Model outputs are extracted from a single model run with the "best" model fit in each site.

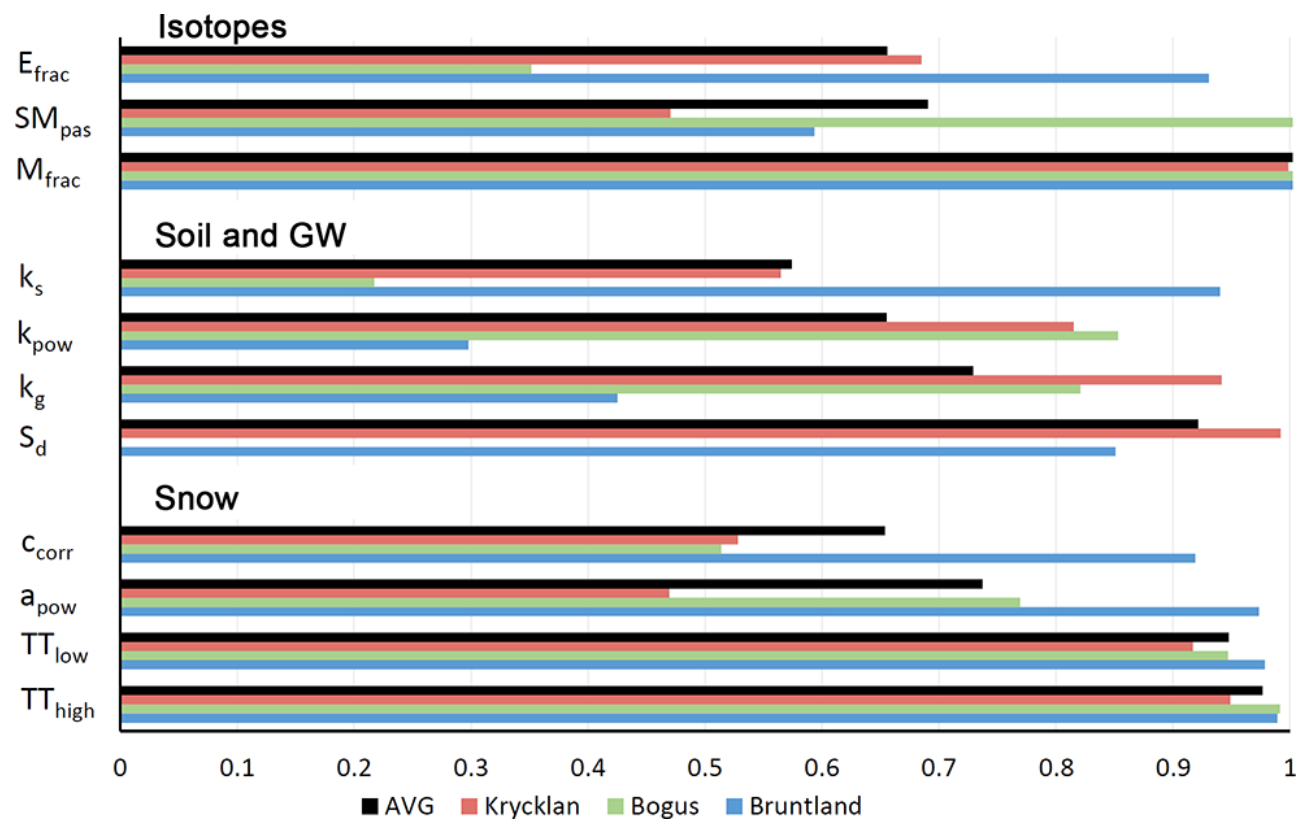

Figure 10. Sensitivity of model parameters shown as ratio of pre- and post-calibration standard deviation - the smaller the ratio, the more constrained the post-calibration parameter interpreted as parameter sensitivity. The parameters are grouped by model modules and organized within modules from most sensitive to least sensitive based on average for all experimental catchments.

KGE for SWE between generally 0.6 and 0.8 , and MAE in isotopes around $0.3-0.5 \%$. The good fits in all three calibration objectives (streamflow, stream isotope tracers, and SWE) are particularly noteworthy because we used exceptionally high quality time series ( 5 to 10 years) - in the context of northern, snow-influenced headwaters - from three long-term experimental watersheds, which inevitably encompass a range of different hydrological conditions and extremes that the model needs to capture. The fact that the model can simultaneously satisfy three calibration objectives over long time periods gives confidence in the model realizations and the resulting water age estimates (McDonnell and Beven, 2014). The spatially distributed model structure would allow further model testing using internal model variables, such as soil and groundwater and snowmelt isotope composition, as done successfully for the sites in Huijgevoort at al. (2016a) and Ala-aho et al. (2017b), respectively. However, with the focus on catchment comparison in this study 
we restrict our analysis to the stream isotopes, which have been sampled in all study sites.

The Krycklan catchment was a strong test of the model adaptability to snow-influenced environments because of its reoccurring winter and exceptionally high quality long-term isotope data sets for snow precipitation, streamflow, and SWE. Moreover, the switch to summer rainfall-dominated events provided an additional challenge. The model, in general, performed well, but the misfit in winter 2007 gives an interesting insight into model failure (Andréassian et al., 2010). That year was exceptional in the data record exhibiting an intensive snowmelt event in late 2006 (Fig. 5) and almost $50 \%$ of snow was lost through snow interception sublimation over the course of winter (Kozii et al., 2017). This was not fully captured by the model and led to overestimation of the simulated snow amount and delayed timing of snowmelt, which in turn resulted in overly depleted stream isotope ratios and overestimated streamflow (Fig. 5). The model's injection of an overestimated flux of depleted snowmelt water into the catchment likely has a carry-over effect underestimating streamflow isotopes through the year 2007 and early 2008. This exceptional event illustrates how intimately snow processes are linked not only to simulating water but also, crucially, to isotope fluxes in northern catchments (Stadnyk et al., 2013; Smith et al., 2016).

For the Bruntland Burn, similar model fits to van Huijgevoort et al. (2016a) were achieved, despite some modifications in the code. This was expected because of using the same input data for the first 3 out of 5 simulation years, but the additional years encompassed extreme events such as a 200-year return period flood at the turn of 2015-2016 giving the model a substantial challenge. Notable misfits in isotope ratios are present in the summer periods of 2014 and 2015 which may be caused by evaporative fractionation from pools in the riparian peat areas - a process not currently included in the model algorithms but one that has been shown to be important in the catchment (Sprenger et al., 2016b). Smith et al. (2016) successfully included the soil evaporative fractionation in their spatially distributed tracer-aided simulations, and similar approaches could be adopted to the STARR model to improve model realism during summer periods with elevated evaporation.

For the Bogus catchment, less-frequent isotope data for precipitation and streamflow were available, but we argue that the available data, though fewer than for other sites, was still very useful in model calibration. In Bogus, both calibration data for streamflow and isotope forced the model to route much of the water through deep flow paths, mobilizing the groundwater storage. Streamflow data enforced a prolonged and damped response to snowmelt. To reproduce this, the model has to divert high volumes of snowmelt water entering the catchment in a short time window without an excessive stream response, requiring high seepage rates to groundwater storage. In addition, measured stream isotope ratios reside close to average winter precipitation $(-16$, $\ldots,-17 \%$ ), inferring a lot of snowmelt recharge and mixing in the subsurface. The model behaviour fits well with the conceptual understanding of the streamflow generation processes in the catchment, where runoff takes place only after the water storage in the subsurface accumulates sufficiently (McNamara et al., 2005; Kelleners et al., 2010). Even though snow cover at the top of the catchment is persistent throughout winter, the catchment lies in the rain-snow transition zone and lower parts of the catchment are likely to experience midwinter snowmelt and rain-on-snow events (Kormos et al., 2014; Evans et al., 2016). The spatially distributed processbased snow routine developed in Ala-aho et al. (2017b) is able to represent the spatial differences in snow accumulation and melt seen in reproducing the midwinter flow peaks in winters 2008/2009 and 2010/2011.

We used 11 parameters in the model calibration at all sites, some of which were distributed for different soil units at Bruntland and Krycklan to reflect differences in soil characteristics and readily established conceptual models for the catchments' runoff generation (Nyberg et al., 2001; Laudon et al., 2004; Birkel et al., 2014; Tetzlaff et al., 2014). Based on our sensitivity analysis we already excluded a number of insensitive model parameters from the calibration process. The parameter sensitivity is not fully comparable across sites, because we decided on slightly different calibration ranges for parameters $S_{\mathrm{d}}, k_{\mathrm{s}}$ and $k_{\text {pow }}$ based on tentative model testing to account for the substantial differences in catchment characteristics and resulting dominant runoff generation processes. We wanted to focus on sampling the "behavioural" ranges of the parameters to improve our chances for good model fits.

\subsection{Spatially distributed water ages reveal runoff generation mechanisms}

The methodology in STARR to track spatially distributed water ages proved very insightful in highlighting differences between catchments and their flow processes. The model allows for water source appointment, i.e. in what part of the catchment and from which model compartment the runoff is being generated (animation S1), comparable to information that can be gained from data-driven hydrograph separation techniques (Rodhe, 1981; Laudon et al., 2002; He et al., 2015). Estimates of stream water age give comparative, integrated signals of what runoff generation processes dominate in the catchment and the timing of their seasonal activation. Such spatially distributed estimates of water ages and their temporal evolution are still limited (Sayama and McDonnell, 2009), in particular in data-sparse northern regions. Other techniques for water age estimations such as transit time distributions (McGuire and McDonnell, 2006), lumped conceptual modelling (Soulsby et al., 2015), or more recent storage selection functions (Rinaldo et al., 2015) do not allow such spatially detailed insight into catchment functioning. Water age distributions highlight the differences between 
catchments (Fig. 8), whereas the age time series (Figs. 5, 6, 7) give insights into runoff generation processes within individual catchments. Spatially distributed animations of the model outputs (S1) provide an intuitive visual tool for both comparison across catchments and identifying spatio-temporal dynamics of runoff generation processes within individual catchments.

The most striking feature when comparing water age probability densities (Fig. 8) is the difference between Bogus and the other sites: both the flat shape of the distribution and old median water age are reflective of long residence time in Bogus. Water age distributions for Bruntland and Krycklan have a heavy-tailed shape commonly encountered in catchment water age or transit time distributions (McGuire and McDonnell, 2006). The main difference between the two is the higher fraction of young ( $<1$ year) water in Krycklan, which can be explained by the lower subsurface storage (Table 2), a strong influence of relatively young snowmelt water (S1), and smaller catchment area (Fig. 1). However, the youngest waters in Krycklan are not from snowmelt events, because snowpack is ageing throughout the winter, thus giving the snowmelt water a typical age of 2-3 months, coinciding with the mode age in Krycklan (Fig. 8). Median water age for Krycklan is $\sim 11$ months, which is slightly below an independent estimate of 1.5-2 years for catchment mean transit time using the convolution integral method to fit a gamma distribution to the same isotope data set (Peralta-Tapia et al., 2016). At Bruntland, the median age of stream water was $\sim 1.5$ years, which is close to the previous STARR application to the site of $\sim 1.6$ years in Huijgevoort et al. (2016a) and in broad agreement with two independent modelling studies yielding median water ages of $\sim 0.9$ and $\sim 1.8$ years (Soulsby et al., 2015; Benettin et al., 2017), respectively, and a convolution integral-based mean transit time estimate of 1.9 years (Hrachowitz et al., 2010).

Time series for water ages (Figs. 5, 6, 7) and the spatial distribution animation for both ages and runoff (Fig. 9 and S1) reveal snow-dominated flow regimes for Krycklan and Bogus with a distinct winter baseflow period with old water, followed by a period of stream water rejuvenation during snowmelt. The oldest water ages in both catchments occur during summer, not winter base flow. We attribute this to active evaporation processes in the model drawing water from groundwater storage (with old age) via capillary flow. Water from GW storage mixes with the water stored in soil storage, ageing the storage. Some of this soil water is routed to the stream (Fig. 4), resulting in old stream water ages. At Bruntland, the water ages are much more event driven, reflecting less marked seasonality that is not dictated by snow but by regular transitions between drier and wetter periods (S1).

We used spatially varied parameterization for soil properties and vegetation where there were sufficient data to do so; a differentiation between mineral and organic soil was made for Bruntland and Krycklan, a detailed soil depth map was used for Bogus, and vegetation LAI was estimated from either vegetation maps (Krycklan) or three canopy height maps (Bruntland and Bogus). Even so, naturally occurring smallscale heterogeneity is known to influence the catchment hydrological response (Beven and Germann, 1982), but it is difficult to represent in hydrological models - one of the persistent problems in hydrological modelling (Blöschl and Sivapalan, 1995; Beven, 2002). Every new introduced element of heterogeneity typically comes with a burden of increased number of parameters (see soil parameterization in Table 1) which can lead to model equifinality issues (Beven, 2006). We opted to minimize the number of calibrated parameters, with the trade-off bringing spatial variability in parameter values only when supported by field data.

Another parameterization issue in our work arises from specifying initial conditions for the groundwater storage for the Monte Carlo runs. If the initial GW storage is not "in balance" with the magnitude of the outflow coefficient $\left(k_{\mathrm{g}}\right)$, which is randomly varied in the calibration, it can lead to $\mathrm{GW}$ storage reduction or increase over time. Our simulations at the Krycklan site show symptoms of such imbalances between the $k_{\mathrm{g}}$ parameter and the initial GW storage, as the variability and median in the simulated stream water age declines over the 10-year period (Fig. 5). The non-stationarity in age suggest that the groundwater influence (GW storage has older water) reduces over time. In further analysis (data not show) in most of the behavioural simulations the total GW storage in Krycklan in fact grows smaller over time. A longer spin-up period for the Krycklan simulations would alleviate the issue, with the burden of increased runtimes. In addition, even though in our simulations the streamflow during winter is well captured (Fig. 5), the isotope composition in some winters does not shift adequately towards more depleted values (isotopes in deep groundwater between -13 and $-14 \%$; Peralta-Tapia et al., 2015b), suggesting a toolow groundwater contribution. The misfit in winter isotopes suggests that the model has problems in switching from soil source to a more depleted groundwater source during winter. It should be pointed out that such analysis and insights are only possible because of the ability of the STARR model to simulate stable water isotopes and water ages - these issues would not become apparent if using only streamflow hydrograph to evaluate the model performance.

\subsection{Algorithms for isotope fractionation snow are crucial for simulating isotope dynamics in northern regions}

To our knowledge, isotopic fractionation from snowpack sublimation (intercepted and ground snow) and snowmelt has not been considered in previous tracer-aided models, though it has been identified as a potentially important process to improve model realism for snow-influenced environments (Fekete et al., 2006; Smith et al., 2016; Delavau et al., 2017). In this work, the novel algorithms for spatially dis- 
tributed snow isotope routines incorporating the processes above, were most extensively tested in the Krycklan simulations. Annually reoccurring snowmelt depletion of streamflow was generally well captured by the model (except for 2007 as previously discussed), often even for the subtle nuances in the depth of depletion peak between years (Fig. 5).

Isotopic fractionation of the snowpack caused by sublimation (see Eq. 2) was essential to include in order to capture the isotopic enrichment of snowpack during the winter for Krycklan. This is to some extent evident in the high sensitivity of the $E_{\text {frac }}$ parameter in Fig. 10, though sensitivity as approximated here does not reveal what parameter values produced good model fits. For Krycklan, the range for the behaviour simulations was 5-15\%o with a median of $8.6 \%$, which means that a sublimative offset was beneficial in enriching the snowpack in heavy isotopes and eventually matching the observed streamflow isotope levels, agreeing with findings in Laudon et al. (2004, 2007). In contrast, although the $E_{\text {frac }}$ parameter was also sensitive in Bogus, it displayed a typical range of $0-5 \%$ with a median of $2.2 \%$, suggesting a need for the model calibration to minimize the impact of snow sublimation fractionation to gain good model fits in streamflow. This agrees with the findings of Evans et al. (2016), who did not find evidence of sublimation fractionation in their detailed measurements of snowpack evolution over one winter in the same catchment. It should be noted that the input data for snowfall for Bogus site was not as comprehensive as for Krycklan; therefore, the additional uncertainty in the model input may mask the sublimation fractionation effects, if present. However, our snowfall inputs were similar to ones estimated for the area in Tappa et al. (2016), and therefore, on average, likely not too far off. The $E_{\text {frac }}$ parameter was insensitive for the Bruntland (Fig. 10), which is not surprising given the considerably smaller snow influence compared to the other two sites (Fig. 6).

In our parsimonious snow isotope simulation approach we did not differentiate between kinetic and equilibrium fractionation in snow sublimation, and we simulated only the $\delta^{18} \mathrm{O}$ isotope because of better data availability in all sites. This simplification prevented us from simulating additional isotopic indices for evaporation, such as the $d$-excess (Dansgaard, 1964), that would indicate deviations from the meteoric water caused by kinetic fractionation. In typical winter conditions with low air temperature and high relative humidity, we would expect the equilibrium fractionation to dominate over kinetic fractionation (Gat and Gonfiantini, 1981), therefore making weather conditions and the differentiation between the two processes of lesser importance. We also did not differentiate between sublimation (ice to vapour) and evaporation (liquid water retained in the snow to vapour). Liquid water evaporation has a smaller equilibrium fractionation factor $(3.5 \%$ ) compared to sublimation $(15 \%$ ), so separating the different processes could lead to smaller simulated fractionation signal. In our approach we lumped the above fractionation processes and their temporal variability caused by meteorological conditions in the $E_{\text {frac }}$ calibration parameter with the purpose of keeping the simulated isotope process complexity to a minimum, which is in line with our conceptual modelling of water in the catchment. The simplified approach is further justified by the limited power of the validation data (isotopes in streamflow) to constrain the additional parameters required for more sophisticated snowpack isotope modelling methods (Taylor et al., 2001).

The parameter $M_{\text {frac }}$ that adjusts the depletion of initial snowmelt water and progressive enrichment through the snowmelt (see Eq. 3) did not appear to exhibit sensitivity in relation to model outputs (Fig. 10). In the model setups there was a strong component of water isotope mixing the soil and/or groundwater storage, with high values of passive storage (behavioural parameter ranges for $\mathrm{SM}_{\mathrm{pas}}$ between 250 and 300 in Krycklan and Bruntland, Table 2) which likely masked the detailed dynamics of a spatially and temporally variable snowmelt signal. The simulated initial snowmelt depletion may become more important in catchments with a rapid routing of snowmelt on frozen soils with reduced permeability (Cooper et al., 1993; Shanley and Chalmers, 1999; Carey and Quinton, 2004). Soil freezing has been shown to promote snowmelt runoff on wetland-covered areas at the Krycklan site (Laudon et al., 2007). The influence of soil freeze/thaw on runoff is not presently parameterized in the STARR model, which could be further developed. Future work should investigate whether the simulated process of temporally progressing snowmelt enrichment becomes important in catchments with a known strong permafrost or seasonal freeze/thaw influence on early runoff. In our parsimonious snow isotope simulations we assume full isotope mixing in the snowpack (Eq. 1) at each daily time step, which is known to conflict with field observations showing that snowpacks typically maintain a layered structure through the winter (Rodhe, 1981; Dahlke and Lyon, 2013). Furthermore, snow sublimation and melt fractionation primarily take place in the top snow layers, and are probably not instantaneously mixed in the snowpack (Claassen and Downey, 1995; Evans et al., 2016), whereas we assume fractionation with respect to the bulk snowpack. However, the error caused by the fullmixing assumption is reduced by the fact that snowpack is typically homogenized during snowmelt when diurnal meltrefreeze processes take place in the snowpack (Taylor et al., 2001; Unnikrishna et al., 2002; Koeniger et al., 2008). The majority of snowpack outflow is generated during the overall snowmelt when isotopes in the snowpack are subjected to mixing, which gives empirical ground to our simplification. The limitations of the snow isotope modelling regarding the full-mixing assumption and potential biases caused by rain-on-snow events and blowing wind redistribution are further discussed in parallel work by Ala-aho et al. (2017b). In that study we also provide further evidence for the usefulness of the snow isotope modelling approach by finding a good agreement between simulated snowmelt isotopes and snowmelt lysimeter data sampled at Bogus and Krycklan. 
With the present study we demonstrate that even with the relatively simple isotope model we are able to produce improved estimates of spatially distributed snowmelt isotopes, which is called for in tracer-aided modelling of sparsely monitored snow-influenced regions (Smith et al., 2016; Delavau et al., 2017). Furthermore, we show that the stream isotopes can be used to inform parameter the snow routine through calibration, in particular for the snow sublimation fractionation.

\section{Conclusions}

Tracer-aided modelling is a powerful tool to study runoff generation processes within a catchment and, as we showed here, in inter-catchment comparison. The spatially distributed STARR modelling framework allowed us to track water age within our experimental catchments in space and time, which gave additional means to analyse the spatially distributed catchment response within and between catchments. It is well known that correctly representing snow processes in northern catchments is important in hydrological modelling and will be increasingly crucial with a warming climate and following changes in snow conditions. In this study, we made a first attempt to link spatially and temporally variable isotope fractionation processes in seasonal snowpacks with a tracer-aided hydrological model. Using longterm data sets for three contrasting northern headwaters, we showed the importance of capturing not only the snow accumulation and melt but also the isotopic composition of snowmelt to reproduce the streamflow isotope ratios. Highfrequency isotope data sets from the Bruntland and Krycklan experimental catchments were invaluable to produce a proof of concept for our modelling method in snow-influenced catchments, but coarser tracer data in the Bogus catchment were also useful in constraining our modelling effort.

Code and data availability. The model codes and the data are available upon request. 


\section{Appendix A}

Table A1. Snow module (for parameters in the model calibration, full description in Ala-aho et al., 2017b).

\begin{tabular}{|c|c|c|}
\hline \multirow{3}{*}{$\begin{array}{l}\text { Thermal quality of precipita- } \\
\text { tion }\end{array}$} & \multirow{3}{*}{ 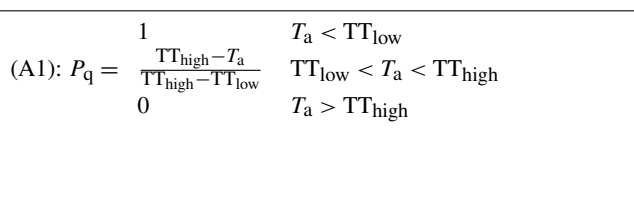 } & \multirow{3}{*}{$\begin{array}{l}T_{\mathrm{a}} \text { : air temperature, } \\
\mathrm{TT}_{\text {low }} \text { : threshold temperature below which all precipitation is } \\
\text { snow } \\
\mathrm{TT}_{\text {high: }} \text { the threshold temperature above which all precipita- } \\
\text { tion is liquid }\end{array}$} \\
\hline & & \\
\hline & & \\
\hline \multirow[t]{2}{*}{$\begin{array}{l}\text { Correction for snow under- } \\
\text { catch }\end{array}$} & (A2): $c_{\text {snow }}=\begin{array}{ll}\left(\frac{\exp \left(4.606-0.036 \times W_{\mathrm{can}}+1 / 5\right)}{100}\right) & T_{\mathrm{a}}<0 \\
\left(\frac{101.04-5.62 \times W_{\text {can }}}{100}\right)^{-1} & T_{\mathrm{a}}>0\end{array}$ & $\begin{array}{l}W_{\text {can }}: \text { wind speed under canopy } \\
c_{\text {corr }} \text { empirical addition correction for snowfall }\end{array}$ \\
\hline & 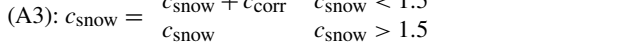 & \\
\hline Rainfall phase separation & $\begin{array}{l}\text { (A4): } P_{\text {liq }}=P \times\left(1-P_{\mathrm{q}}\right) \\
\text { (A5): } P_{\text {ice }}=P \times P_{\mathrm{q}} \times c_{\text {snow }}\end{array}$ & $P:$ measured precipitation \\
\hline Reduction of snow albedo & $\begin{array}{l}\text { (A6): } a=0.94^{d_{\mathrm{ns}} 0.58} \\
\text { (A7): } a=a^{a_{\mathrm{pow}}}\end{array}$ & $\begin{array}{l}d_{\text {ns }}: \text { days without snowfall } \\
a_{\text {pow }}: \text { coefficient to reduce snow albedo in snowpacks older } \\
\text { than } 100 \text { days }\end{array}$ \\
\hline \multicolumn{3}{|l|}{ Soil module } \\
\hline Evaporation soil & $\begin{array}{l}\text { (A8): } \mathrm{ET}=\mathrm{PET} \times \min \left(\frac{\mathrm{SM}}{\mathrm{FC} \times \mathrm{LP}}, 1\right) \\
\text { (A9): } \mathrm{FC}=f_{\text {cap }} \times S_{d}\end{array}$ & $\begin{array}{l}\text { PET: potential evaporation } \\
\text { SM: soil moisture } \\
\text { LP: fraction of limiting actual evaporation } \\
\text { FC: field capacity } \\
f_{\text {cap }} \text { : the volumetric field capacity } \\
S_{\mathrm{d}} \text { : the soil depth } \\
\theta \text { : soil porosity }\end{array}$ \\
\hline $\begin{array}{l}\text { Recharge from soil to the } \\
\text { groundwater }\end{array}$ & \multirow{2}{*}{$\begin{array}{l}\text { (A10): Seep }=\beta_{\text {seep }}\left(\frac{\mathrm{SM}}{\mathrm{FC}}\right)^{\beta_{\mathrm{pow}}} \\
\text { When } \mathrm{SM}>\mathrm{FC}: \\
\text { (A11): Seepage }=\operatorname{MIN}(\mathrm{SM}-\mathrm{FC}, \text { Seepage })\end{array}$} & $\begin{array}{l}\beta_{\text {seep }} \text { recession coefficient to determine soil recharge into } \\
\text { groundwater }\end{array}$ \\
\hline & & $\beta_{\text {pow }}$ power coefficient \\
\hline Soil discharge & (A12): $Q_{\text {soil }}=k_{\mathrm{s}}\left(\frac{\mathrm{SM}}{\mathrm{FC}}\right)^{k_{\mathrm{pow}}}$ & $\begin{array}{l}k_{\mathrm{s}} \text { : recession coefficient to determine outflow from soil stor- } \\
\text { age } \\
k_{\text {now }} \text { : power coefficient }\end{array}$ \\
\hline Direct runoff & $\begin{array}{l}\text { (A13): } Q_{\text {storm }}=\max \left(\mathrm{SM}-\mathrm{SM}_{\max }\right. \\
\text { (A14): } \mathrm{SM}_{\max }=\theta \cdot S_{\mathrm{d}}\end{array}$ & $\mathrm{SM}_{\max }:$ maximum soil storage; \\
\hline $\begin{array}{l}\text { Capillary flux from groundwa- } \\
\text { ter }\end{array}$ & $(\mathrm{A} 15): \mathrm{Cap}=C_{\mathrm{flux}} \times\left(\frac{\mathrm{FC}-\mathrm{SM}}{\mathrm{FC}}\right)$ & $C_{\text {flux }}:$ parameter for maximum capillary flux \\
\hline Soil moisture store & $\begin{array}{l}\text { (A16): } \mathrm{SM}(t)=\mathrm{SM}(t-1)+P_{\text {eff }}-\mathrm{ET}-Q_{\text {soil }}- \\
Q_{\text {storm }}-\text { Seep }+ \text { Cap }\end{array}$ & $\begin{array}{l}P_{\text {eff: }} \text { effective precipitation (sum throughfall, stemflow and } \\
\text { snowmelt) }\end{array}$ \\
\hline \multicolumn{3}{|l|}{ Groundwater module } \\
\hline Groundwater discharge & (A17): $Q_{\mathrm{gw}}=k_{\mathrm{g}} \mathrm{GW}$ & $\begin{array}{l}\mathrm{kg}_{\mathrm{g}} \text { : recession coefficient baseflow } \\
\mathrm{GW} \text { : groundwater store }\end{array}$ \\
\hline Lateral groundwater flow & (A18): $Q_{\mathrm{lf}}=k_{\mathrm{sat}} \operatorname{slope}(\mathrm{DEM}+\mathrm{GW})$ & $\begin{array}{l}k_{\text {sat }} \text { : saturated conductivity } \\
\text { DEM: elevation difference between cells }\end{array}$ \\
\hline Groundwater store & (A19): $\mathrm{GW}(t)=\mathrm{GW}(t-1)+$ Seep $-Q_{\mathrm{gw}}+\Delta Q_{\mathrm{lf}}-$ Cap & $\Delta Q_{\mathrm{lf}}:$ net lateral flow \\
\hline \multicolumn{3}{|l|}{ Routing } \\
\hline Total discharge & $\begin{array}{l}(\mathrm{A} 20): Q_{\text {tot, cell }}=Q_{\text {storm }}+Q_{\text {soil }}+Q_{\mathrm{gw}} \\
\text { (A21): } Q_{\text {tot }}=\text { accutraveltimeflux(lddQ } Q_{\text {tot }} \text { velocity) }\end{array}$ & $\begin{array}{l}\text { ldd: map with local drainage direction } \\
\text { accutraveltimeflux: routing function in PCRaster* }\end{array}$ \\
\hline \multicolumn{3}{|l|}{ Isotope ratios } \\
\hline Isotope ratio soil $\left(i_{\mathrm{s}}\right)$ & $\begin{array}{l}(\mathrm{A} 22): \quad \frac{d i_{\mathrm{s}}\left(\mathrm{SM}+\mathrm{SM} \mathrm{pas}_{\mathrm{s}}\right)}{\mathrm{d} t}=i_{\mathrm{p}} P_{\text {eff }}-i_{\text {soil }} Q_{\text {storm }}-i_{\text {soil }} Q_{\text {soil }}- \\
i_{\text {soil }} \mathrm{ET}-i_{\text {soil }} \mathrm{Seep}+i_{\mathrm{gw}} \text { Cap }\end{array}$ & $\begin{array}{l}i_{\mathrm{p}}: \text { isotope ratios' effective precipitation } \\
i_{\text {soil }}: \text { isotope ratios in soil storage } \\
i_{\mathrm{gw}}: \text { isotope ratios in groundwater storage } \\
\mathrm{SM}_{\text {pas }}: \text { passive storage component }\end{array}$ \\
\hline $\begin{array}{l}\text { Isotope ratio groundwater } \\
\left(i_{\mathrm{gw}}\right)\end{array}$ & $\begin{array}{l}\text { (A23): } \frac{d i_{\mathrm{gw}}(\mathrm{GW})}{\mathrm{d} t}=i_{\mathrm{soil}} \mathrm{Seep}-i_{\mathrm{gw}} \mathrm{Cap}-i_{\mathrm{gw}} Q_{\mathrm{gw}}-i_{\mathrm{gw}} Q_{\mathrm{lf}, \text { out }}+ \\
i_{\mathrm{gw}, \text { up }} Q_{\mathrm{lf}, \mathrm{in}}\end{array}$ & $i_{\mathrm{gw}, \text { up }}$ isotope ratios inflow lateral groundwater flow \\
\hline \multicolumn{3}{|l|}{ Water ages } \\
\hline $\begin{array}{l}\text { Water age groundwater } \\
\left(\mathrm{Age}_{\mathrm{GW}}\right)\end{array}$ & $\begin{array}{l}\text { (A24): } \frac{d \mathrm{Age}_{\mathrm{SM}}(\mathrm{SM}+\mathrm{SMpas})}{\mathrm{d} t}=\mathrm{Age}_{\mathrm{P}} P_{\text {eff }}-\mathrm{Age}_{\mathrm{SM}} \times Q_{\text {soil }}-1 \times \\
Q_{\text {storm }}-\mathrm{Age}_{\mathrm{SM}} \times \mathrm{ET}-\mathrm{Age}_{\mathrm{SM}} \times \mathrm{Seep}+\mathrm{Age}_{\mathrm{GW}} \times \mathrm{Cap} \\
\left(\mathrm{A}_{25}\right): \quad \frac{d \mathrm{Age}_{\mathrm{GW}}(\mathrm{GW})}{\mathrm{d} t}=\mathrm{Age}_{\mathrm{SM}} \times \mathrm{Seep}-\mathrm{Age}_{G W} \times \mathrm{Cap}- \\
\mathrm{Age}_{\mathrm{GW}} \times Q_{\mathrm{gg}}-\mathrm{Age}_{\mathrm{GW}} \times Q_{\mathrm{lf}_{\text {,out }}}+\mathrm{Age}_{\mathrm{GW}, \text { up }} \times Q_{\mathrm{lf}, \text { in }}\end{array}$ & Age $_{\mathrm{p}}$ : age of the precipitation (for rain equal to 1 ) \\
\hline
\end{tabular}

PCRaster documention, http://pcraster.geo.uu.nl/pcraster/4.1.0/doc/manual/index.html. 


\section{The Supplement related to this article is available online at https://doi.org/10.5194/hess-21-5089-2017- supplement.}

Author contributions. PA adapted a model developed in earlier work led by CS and DT and carried out the modelling. Data used for model calibration and testing were collected by HL, JPM, CS, and DT for the study sites. All authors were involved in the data and model interpretation. PA prepared the paper with contributions from all co-authors.

Competing interests. The authors declare that they have no conflict of interest.

Acknowledgements. This work was funded by the NERC/JPI SIWA project (NE/M019896/1) and the European Research Council ERC (project GA 335910 VeWa). Numerical simulations were performed using the Maxwell High Performance Computing Cluster of the University of Aberdeen IT Service, provided by Dell Inc. and supported by Alces Software. The isotope work in Krycklan is funded by the KAW Branch-Point project together with SKB and SITES. We would like to thank Marjolein van Huijgevoort for her help with the STARR code, and Masaki Hayashi and two anonymous reviewers for their insightful suggestions that significantly improved the paper.

Edited by: Hannah Cloke

Reviewed by: Masaki Hayashi and two anonymous referees

\section{References}

Ala-aho, P., Soulsby, C., Wang, H., and Tetzlaff, D.: Integrated surface-subsurface model to investigate the role of groundwater in headwater catchment runoff generation: a minimalist approach to parameterisation, J. Hydrol., 547, 664-677, 2017a.

Ala-aho, P., Tetzlaff, D., McNamara, J. P., Laudon, H., Kormos, P., and Soulsby, C.: Modelling the isotopic evolution of snowpack and snowmelt: testing a spatially distributed parsimonious approach, Water Resour. Res, 53, 5813-5830, https://doi.org/10.1002/2017WR020650, 2017 b.

Andréassian, V., Perrin, C., Parent, E., and Bárdossy, A.: The Court of Miracles of Hydrology: can failure stories contribute to hydrological science?, Hydrol. Sci J., 55, 849-856, 2010.

Barnes, C. and Bonell, M.: Application of unit hydrograph techniques to solute transport in catchments, Hydrol. Process., 10, 793-802, 1996.

Barnett, T. P., Adam, J. C., and Lettenmaier, D. P.: Potential impacts of a warming climate on water availability in snow-dominated regions, Nature, 438, 303-309, 2005.

Benettin, P., Soulsby, C., Birkel, C., Tetzlaff, D., Botter, G., and Rinaldo, A.: Using SAS functions and high resolution isotope data to unravel travel time distributions in headwater catchments, Water Resour. Res., 53, 1864-1878, https://doi.org/10.1002/2016WR020117, 2017.
Berghuijs, W., Woods, R., and Hrachowitz, M.: A precipitation shift from snow towards rain leads to a decrease in streamflow, Nature Climate Change, 4, 583-586, 2014.

Berman, E. S., Gupta, M., Gabrielli, C., Garland, T., and McDonnell, J. J.: High-frequency field-deployable isotope analyzer for hydrological applications, Water Resour. Res., 45, W10201, https://doi.org/10.1029/2009WR008265, 2009.

Beven, K.: Towards an alternative blueprint for a physically based digitally simulated hydrologic response modelling system, Hydrol. Process., 16, 189-206, 2002.

Beven, K.: A manifesto for the equifinality thesis, J. Hydrol., 320, 18-36, 2006.

Beven, K. and Germann, P.: Macropores and water flow in soils, Water Resour. Res., 18, 1311-1325, 1982.

Birkel, C. and Soulsby, C.: Advancing tracer-aided rainfall-runoff modelling: a review of progress, problems and unrealised potential, Hydrol. Process., 29, 5227-5240, 2015.

Birkel, C., Soulsby, C., and Tetzlaff, D.: Conceptual modelling to assess how the interplay of hydrological connectivity, catchment storage and tracer dynamics controls nonstationary water age estimates, Hydrol. Process., 29, 2956-2969, 2015.

Birkel, C., Soulsby, C., and Tetzlaff, D.: Developing a consistent process-based conceptualization of catchment functioning using measurements of internal state variables, Water Resour. Res., 50, 3481-3501, 2014

Birkel, C., Tetzlaff, D., Dunn, S. M., and Soulsby, C.: Using time domain and geographic source tracers to conceptualize streamflow generation processes in lumped rainfall-runoff models, Water Resour. Res., 47, W02515, https://doi.org/10.1029/2010WR009547, 2011.

Blöschl, G. and Sivapalan, M.: Scale issues in hydrological modelling: a review, Hydrol. Process., 9, 251-290, 1995.

Boise State University: Dry Creek Experimental Watershed online database, available at: https://earth.boisestate.edu/drycreek/data/, last access: 9 February 2017.

Carey, S. and Quinton, W.: Evaluating snowmelt runoff generation in a discontinuous permafrost catchment using stable isotope, hydrochemical and hydrometric data, Hydrol. Res., 35, 309-324, 2004.

Claassen, H. and Downey, J.: A model for deuterium and oxygen 18 isotope changes during evergreen interception of snowfall, Water Resour. Res., 31, 601-618, 1995.

Cooper, L. W., Solis, C., Kane, D. L., and Hinzman, L. D.: Application of oxygen-18 tracer techniques to arctic hydrological processes, Arct. Alp. Res., 247-255, 1993.

Dahlke, H. E. and Lyon, S. W.: Early melt season snowpack isotopic evolution in the Tarfala valley, northern Sweden, Ann. Glaciol. 54, 149-156, 2013.

Dansgaard, W.: Stable isotopes in precipitation, Tellus, 16, 436468, 1964.

Delavau, C. J., Stadnyk, T., and Holmes, T.: Examining the impacts of precipitation isotope input $\left({ }^{18} \mathrm{O}_{\mathrm{ppt}}\right)$ on distributed, tracer-aided hydrological modelling, Hydrol. Earth Syst. Sci., 21, 2595-2614, https://doi.org/10.5194/hess-21-2595-2017, 2017.

Earman, S., Campbell, A. R., Phillips, F. M., and Newman, B. D.: Isotopic exchange between snow and atmospheric water vapor: Estimation of the snowmelt component of groundwater recharge in the southwestern United States, J. Geophys. Res. 111, D09302, https://doi.org/10.1029/2005JD006470, 2006. 
Ellehoj, M., Steen-Larsen, H. C., Johnsen, S. J., and Madsen, M. B.: Ice-vapor equilibrium fractionation factor of hydrogen and oxygen isotopes: Experimental investigations and implications for stable water isotope studies, Rapid Commun. Mass Spectrom., 27, 2149-2158, 2013.

Evans, S. L., Flores, A. N., Heilig, A., Kohn, M. J., Marshall, H., and McNamara, J. P.: Isotopic evidence for lateral flow and diffusive transport, but not sublimation, in a sloped seasonal snowpack, Idaho, USA, Geophys. Res. Lett., 43, 3298-3306, 2016.

Fekete, B. M., Gibson, J. J., Aggarwal, P., and Vörösmarty, C. J.: Application of isotope tracers in continental scale hydrological modeling, J. Hydrol., 330, 444-456, 2006.

Feng, X., Taylor, S., Renshaw, C. E., and Kirchner, J. W.: Isotopic evolution of snowmelt 1 . A physically based one-dimensional model, Water Resour. Res., 38, 35-1-35-8, 2002.

Gat, J. R. and Gonfiantini, R.: Stable isotope hydrology, Deuterium and oxygen-18 in the water cycle, IAEA, Vienna, 1981.

Goody, R. M. and Yung, Y. L.: Atmospheric radiation: theoretical basis, Oxford University Press, 1995.

Gupta, H. V., Kling, H., Yilmaz, K. K., and Martinez, G. F.: Decomposition of the mean squared error and NSE performance criteria: Implications for improving hydrological modelling, J. Hydrol., 377, 80-91, 2009.

He, Z. H., Tian, F. Q., Gupta, H. V., Hu, H. C., and Hu, H. P.: Diagnostic calibration of a hydrological model in a mountain area by hydrograph partitioning, Hydrol. Earth Syst. Sci., 19, 18071826, https://doi.org/10.5194/hess-19-1807-2015, 2015.

Hedstrom, N. and Pomeroy, J.: Measurements and modelling of snow interception in the boreal forest, Hydrol. Process., 12, 1611-1625, 1998.

Hinzman, L. D. and Kane, D. L.: Snow hydrology of a headwater arctic basin: 2. Conceptual analysis and computer modeling, Water Resour. Res., 27, 1111-1121, 1991.

Hrachowitz, M., Soulsby, C., Tetzlaff, D., and Speed, M.: Catchment transit times and landscape controls - does scale matter?, Hydrol. Process., 24, 117-125, 2010.

Hrachowitz, M., Savenije, H., Bogaard, T. A., Tetzlaff, D., and Soulsby, C.: What can flux tracking teach us about water age distribution patterns and their temporal dynamics?, Hydrol. Earth Syst. Sci., 17, 533-564, https://doi.org/10.5194/hess-17-5332013, 2013.

Huijgevoort, M. H. J., Tetzlaff, D., Sutanudjaja, E. H., and Soulsby, C.: Using high resolution tracer data to constrain water storage, flux and age estimates in a spatially distributed rainfall-runoff model, Hydrol. Process., 30, 4761-4778, https://doi.org/10.1002/hyp.10902, 2016a.

Huijgevoort, M., Tetzlaff, D., Sutanudjaja, E., and Soulsby, C.: Visualization of spatial patterns of connectivity and runoff ages derived from a tracer-aided model, Hydrol. Process., 25, 48934895, https://doi.org/10.1002/hyp.10961, 2016b.

Karlsen, R. H., Grabs, T., Bishop, K., Buffam, I., Laudon, H., and Seibert, J.: Landscape controls on spatiotemporal discharge variability in a boreal catchment, Water Resour. Res., 52, 6541-6556, 2016.

Karssenberg, D., Schmitz, O., Salamon, P., de Jong, K., and Bierkens, M. F. P.: A software framework for construction of process-based stochastic spatio-temporal models and data assimilation, Environ. Modell. Softw., 25, 489-502, 2010.
Kelleners, T., Chandler, D., McNamara, J. P., Gribb, M. M., and Seyfried, M.: Modeling runoff generation in a small snowdominated mountainous catchment, Vadose Zone J., 9, 517-527, 2010.

Kirchner, J. W.: Getting the right answers for the right reasons: Linking measurements, analyses, and models to advance the science of hydrology, Water Resour. Res., 42, W03S04, https://doi.org/10.1029/2005WR004362, 2006.

Koeniger, P., Hubbart, J. A., Link, T., and Marshall, J. D.: Isotopic variation of snow cover and streamflow in response to changes in canopy structure in a snow-dominated mountain catchment, Hydrol. Process., 22, 557-566, 2008.

Kormos, P. M.: Accounting for Time and Space Variations of $\delta^{18}$ in a Snowmelt Isotopic Hydrograph Separation in the Boise Front, MSc thesis/masters, Boise State University Thesis and Dissertations 916, Boise, Idaho, USA, 1-57, 2005.

Kormos, P. R., Marks, D., McNamara, J. P., Marshall, H., Winstral, A., and Flores, A. N.: Snow distribution, melt and surface water inputs to the soil in the mountain rain-snow transition zone, J. Hydrol., 519, 190-204, 2014.

Kozii, N., Laudon, H., Löfvenius, M. O., and Hasselquist, N. J.: Increasing water losses from snow captured in the canopy of boreal forests: A case study using a 30 year data set from northern Sweden, Hydrol. Process., 31, 3558-3567, https://doi.org/10.1002/hyp.11277, 2017.

Laudon, H. and Löfvenius, M. O.: Adding snow to the pictureproviding complementary winter precipitation data to the krycklan catchment study database, Hydrol. Process., 30, 2413-2416, 2016.

Laudon, H., Hemond, H. F., Krouse, R., and Bishop, K. H.: Oxygen 18 fractionation during snowmelt: implications for spring flood hydrograph separation, Water Resour. Res., 38, 1258, https://doi.org/10.1029/2002WR001510, 2002.

Laudon, H., Seibert, J., Köhler, S., and Bishop, K.: Hydrological flow paths during snowmelt: Congruence between hydrometric measurements and oxygen 18 in meltwater, soil water, and runoff, Water Resour. Res., 40, W03102, https://doi.org/10.1029/2003WR002455, 2004.

Laudon, H., Sjöblom, V., Buffam, I., Seibert, J., and Mörth, M.: The role of catchment scale and landscape characteristics for runoff generation of boreal streams, J. Hydrol., 344, 198-209, 2007.

Laudon, H., Taberman, I., Ågren, A., Futter, M., OttossonLöfvenius, M., and Bishop, K.: The Krycklan Catchment Study - a flagship infrastructure for hydrology, biogeochemistry, and climate research in the boreal landscape, Water Resour. Res., 49, 7154-7158, 2013.

Lehning, M., Bartelt, P., Brown, B., and Fierz, C.: A physical SNOWPACK model for the Swiss avalanche warning: Part III: meteorological forcing, thin layer formation and evaluation, Cold Reg. Sci. Technol., 35, 169-184, 2002.

Lindström, G., Johansson, B., Persson, M., Gardelin, M., and Bergström, S.: Development and test of the distributed HBV-96 hydrological model, J. Hydrol., 201, 272-288, 1997.

Liston, G. E. and Elder, K.: A distributed snow-evolution modeling system (SnowModel), J. Hydrometeorol., 7, 1259-1276, 2006.

McDonnell, J. J. and Beven, K.: Debates - The future of hydrological sciences: A (common) path forward? A call to action aimed at understanding velocities, celerities and residence time distri- 
butions of the headwater hydrograph, Water Resour. Res., 50, 5342-5350, 2014.

McGuire, K. J. and McDonnell, J. J.: A review and evaluation of catchment transit time modeling, J. Hydrol., 330, 543-563, 2006.

McNamara, J. P., Chandler, D., Seyfried, M., and Achet, S.: Soil moisture states, lateral flow, and streamflow generation in a semiarid, snowmelt-driven catchment, Hydrol. Process., 19, 40234038, 2005.

MET Office: MIDAS: Global Radiation Observations. NCAS British Atmospheric Data Centre, available at: http://catalogue. ceda.ac.uk/uuid/b4c028814a666a651f52f2b37a97c7c7, last access: 11 January 2017.

Moser, H. and Stichler, W.: Deuterium and oxygen-18 contents as an index of the properties of snow covers, International Association of Hydrological Sciences Publication, 114, 122-135, 1974.

National Climatic Data Center: NESDIS, NOAA, US Department of Commerce, Site no 978 Bogus Basin, available at: http://wcc. sc.egov.usda.gov/nwcc/site?sitenum $=978$, last access: 7 January 2016.

Neal, C., Christophersen, N., Neale, R., Smith, C. J., Whitehead, P. G., and Reynolds, B.: Chloride in precipitation and streamwater for the upland catchment of river severn, mid-wales; some consequences for hydrochemical models, Hydrol. Process., 2, 155165,1988 .

Nyberg, L., Stähli, M., Mellander, P., and Bishop, K. H.: Soil frost effects on soil water and runoff dynamics along a boreal forest transect: 1. Field investigations, Hydrol. Process., 15, 909-926, 2001.

Päivänen, J.: Hydraulic conductivity and water retention in peat soils., Acta Forestalia Fennica, Society of Forestry in Finland, Helsinki, Finland, 129, 1973.

Peralta-Tapia, A., Sponseller, R. A., Tetzlaff, D., Soulsby, C., and Laudon, H.: Connecting precipitation inputs and soil flow pathways to stream water in contrasting boreal catchments, Hydrol. Process., 29, 3546-3555, 2015a.

Peralta-Tapia, A., Sponseller, R. A., Ågren, A., Tetzlaff, D., Soulsby, C., and Laudon, H.: Scale-dependent groundwater contributions influence patterns of winter baseflow stream chemistry in boreal catchments, Biogeosciences, 120, 847-858, https://doi.org/10.1002/2014JG002878, 2015b.

Peralta-Tapia, A., Soulsby, C., Tetzlaff, D., Sponseller, R., Bishop, K., and Laudon, H.: Hydroclimatic influences on non-stationary transit time distributions in a boreal headwater catchment, J. Hydrol., 543, 7-16, 2016.

Pomeroy, J., Gray, D., Brown, T., Hedstrom, N., Quinton, W., Granger, R., and Carey, S.: The cold regions hydrological model: a platform for basing process representation and model structure on physical evidence, Hydrol. Process., 21, 2650-2667, 2007.

Rinaldo, A., Benettin, P., Harman, C. J., Hrachowitz, M., McGuire, K. J., Van Der Velde, Y., Bertuzzo, E., and Botter, G.: Storage selection functions: A coherent framework for quantifying how catchments store and release water and solutes, Water Resour. Res., 51, 4840-4847, 2015.

Rodhe, A.: Spring flood meltwater or groundwater?, Hydrol. Res., 12, 21-30, 1981.

Sayama, T. and McDonnell, J. J.: A new time-space accounting scheme to predict stream water residence time and hydrograph source components at the watershed scale, Water Resour. Res., 45, W07401, https://doi.org/10.1029/2008WR007549, 2009.
Schmieder, J., Hanzer, F., Marke, T., Garvelmann, J., Warscher, M., Kunstmann, H., and Strasser, U.: The importance of snowmelt spatiotemporal variability for isotope-based hydrograph separation in a high-elevation catchment, Hydrol. Earth Syst. Sci., 20, 5015-5033, https://doi.org/10.5194/hess-20-5015-2016, 2016.

Seibert, J.: Regionalisation of parameters for a conceptual rainfallrunoff model, Agr. Forest Meteorol., 98, 279-293, 1999.

Seibert, J. and McDonnell, J. J.: On the dialog between experimentalist and modeler in catchment hydrology: Use of soft data for multicriteria model calibration, Water Resour. Res., 38, 1241, https://doi.org/10.1029/2001WR000978, 2002.

Sevruk, B. and Mieglitz, K.: The effect of topography, season and weather situation on daily precipitation gradients in 60 Swiss valleys, Water Sci. Ttechnol., 45, 41-48, 2002.

Shanley, J. B. and Chalmers, A.: The effect of frozen soil on snowmelt runoff at Sleepers River, Vermont, Hydrol. Process., 13, 1843-1857, 1999.

Shanley, J. B., Kendall, C., Albert, M. R., and Hardy, J. P.: Chemical and isotopic evolution of a layered eastern US snowpack and its relation to stream-water composition, IAHS Publications-Series of Proceedings and Reports-Intern Assoc Hydrological Sciences, 228, 329-338, 1995.

Sklash, M. G. and Farvolden, R. N.: The Role Of Groundwater In Storm Runoff, Dev. Water Sci., 12, 45-65, 1979.

Smith, A., Welch, C., and Stadnyk, T.: Assessment of a lumped coupled flow-isotope model in data scarce Boreal catchments, Hydrol. Process., 30, 3871-3884, https://doi.org/10.1002/hyp.10835, 2016.

Soulsby, C., Birkel, C., Geris, J., Dick, J., Tunaley, C., and Tetzlaff, D.: Stream water age distributions controlled by storage dynamics and nonlinear hydrologic connectivity: Modeling with high-resolution isotope data, Water Resour. Res., 51, 7759-7776, 2015.

Sprenger, M., Seeger, S., Blume, T., and Weiler, M.: Travel times in the vadose zone: Variability in space and time, Water Resour. Res., 52, 5727-5754, 2016a.

Sprenger, M., Tetzlaff, D., Tunaley, C., Dick, J., and Soulsby, C.: Evaporation fractionation in a peatland drainage network affects stream water isotope composition, Water Resour. Res., 53, 851866, https://doi.org/10.1002/2016WR019258, 2016 b.

Stadnyk, T. A., Delavau, C., Kouwen, N., and Edwards, T. W. D.: Towards hydrological model calibration and validation: simulation of stable water isotopes using the isoWATFLOOD model, Hydrol. Process., 27, 3791-3810, 2013.

Stone, P. H. and Carlson, J. H.: Atmospheric lapse rate regimes and their parameterization, J. Atmos. Sci., 36, 415-423, 1979.

Tappa, D. J., Kohn, M. J., McNamara, J. P., Benner, S. G., and Flores, A. N.: Isotopic composition of precipitation in a topographically steep, seasonally snow-dominated watershed and implications of variations from the Global Meteoric Water Line, Hydrol. Process., 30, 4582-4592, 2016.

Tarboton, D. G. and Luce, C. H.: Utah energy balance snow accumulation and melt model (UEB), Utah Water Research Laboratory and USDA Forest Service, 1996.

Taylor, S., Feng, X., Kirchner, J. W., Osterhuber, R., Klaue, B., and Renshaw, C. E.: Isotopic evolution of a seasonal snowpack and its melt, Water Resour. Res., 37, 759-769, 2001. 
Taylor, S., Feng, X., Williams, M., and McNamara, J.: How isotopic fractionation of snowmelt affects hydrograph separation, Hydrol. Process., 16, 3683-3690, 2002.

Tesfa, T. K., Tarboton, D. G., Chandler, D. G., and McNamara, J. P.: Modeling soil depth from topographic and land cover attributes, Water Resour. Res., 45, W10438, https://doi.org/10.1029/2008WR007474, 2009

Tetzlaff, D., Birkel, C., Dick, J., Geris, J., and Soulsby, C.: Storage dynamics in hydropedological units control hillslope connectivity, runoff generation, and the evolution of catchment transit time distributions, Water Resour. Res., 50, 969-985, 2014.

Tetzlaff, D., Buttle, J., Carey, S. K., Huijgevoort, M. H., Laudon, H., McNamara, J. P., Mitchell, C. P., Spence, C., Gabor, R. S., and Soulsby, C.: A preliminary assessment of water partitioning and ecohydrological coupling in northern headwaters using stable isotopes and conceptual runoff models, Hydrol. Process., 29, 5153-5173, 2015a.
Tetzlaff, D., Buttle, J., Carey, S. K., McGuire, K., Laudon, H., and Soulsby, C.: Tracer-based assessment of flow paths, storage and runoff generation in northern catchments: a review, Hydrol. Process., 29, 3475-3490, 2015b.

Tetzlaff, D., Carey, S. K., McNamara, J. P., Laudon, H., and Soulsby, C.: The essential value of long-term experimental data for hydrology and water management, Water Resour. Res., 53, 2598-2604, 2017.

Unnikrishna, P. V., McDonnell, J. J., and Kendall, C.: Isotope variations in a Sierra Nevada snowpack and their relation to meltwater, J. Hydrol., 260, 38-57, 2002.

Walter, M. T., Brooks, E. S., McCool, D. K., King, L. G., Molnau, M., and Boll, J.: Process-based snowmelt modeling: does it require more input data than temperature-index modeling?, J. Hydrol., 300, 65-75, 2005.

Wigmosta, M. S., Vail, L. W., and Lettenmaier, D. P.: A distributed hydrology-vegetation model for complex terrain, Water Resour. Res., 30, 1665-1679, 1994. 